\title{
THE INSULA OF THE MENANDER AT POMPEII: INTERIM REPORT
}

\author{
By ROGER LING, F.S.A.
}

\section{INTRODUCTION}

THE British project in the Insula of the Menander at Pompeii was instituted in 1978 by the late Dr. J. B. Ward-Perkins in consultation with the then Superintendent of Antiquities for Campania, Professor Fausto Zevi. Funding has until now been provided by a generous grant from Imperial Tobacco Ltd., a proportion of the profits of the exhibition 'Pompeii 79 ' held at the Royal Academy of Arts, London, in 1976-7. To these mentors and sponsors the author is deeply indebted-to Imperial Tobacco for their enlightened patronage of archaeological research, to Professor Zevi for first suggesting a programme of recording and analysis in the Insula of the Menander, and above all to Dr. Ward-Perkins for taking up the suggestion and largely shaping the present project. This project is in a very real sense his brainchild, and it is as a tribute to his memory that we intend to continue with it and bring it to completion in the manner that he would have wished.

Special thanks must also be given to Dr. Stefano De Caro, the Director of the site at Pompeii, who has been unfailingly courteous and helpful over the past five years, and to his henchmen, Dr. Federico, the assistant director, Sig. Pelli, the technical director, Sig. Cirillo, his assistant, and Sig. Sicignano, the head foreman, for their invaluable practical assistance. Finally, mention must be made of the chief members of the team. After a brief exploratory season in September 1978, full programmes of work have been conducted in August-September 1979, 1980, 1981 and 1982. The writer has acted as site director, Sheila Gibson and Diana Mitchell as architects, and Sheena Howarth, Lesley Ling, David Neal and several others as draughtsmen. Dr. Ward-Perkins played an active role in 1978 and was again present for part of the season in 1979; both he and Dr. J. J. Coulton, who stayed for a week in 1979 , made major contributions to the interpretation of the architecture.

The programme of recording is now over half complete, and the moment has arrived to present an interim report. Since the actual techniques of recording have been summarized elsewhere, ${ }^{1}$ this report will concentrate on the second main aspect of the work: the analysis of the structural development of the insula. The value of this analysis will be examined in pp. 53-5. It has proved possible to throw light on the fluctuating nature of property boundaries, to trace the expansion and contraction of one of the major houses in Pompeii, and to substantiate many of the generalizations made about the social history of Pompeii in its later years. A full study of the finds remains to be done, but promises to add still more to the picture of social life in the insula before A.D. 79 .

\section{General Background (figs. I-5)}

Insula I 1o, the Insula del Menandro, is one of the slightly irregular blocks lying between the presumed old part of the city (the 'Altstadt', roughly equivalent to the area south of Via della Fortuna and west of Via di Stabia) and the regular rectangular grid which fills the eastern part of the final walled city (the 'Neustadt') (fig. I). It is reasonable to assume that 


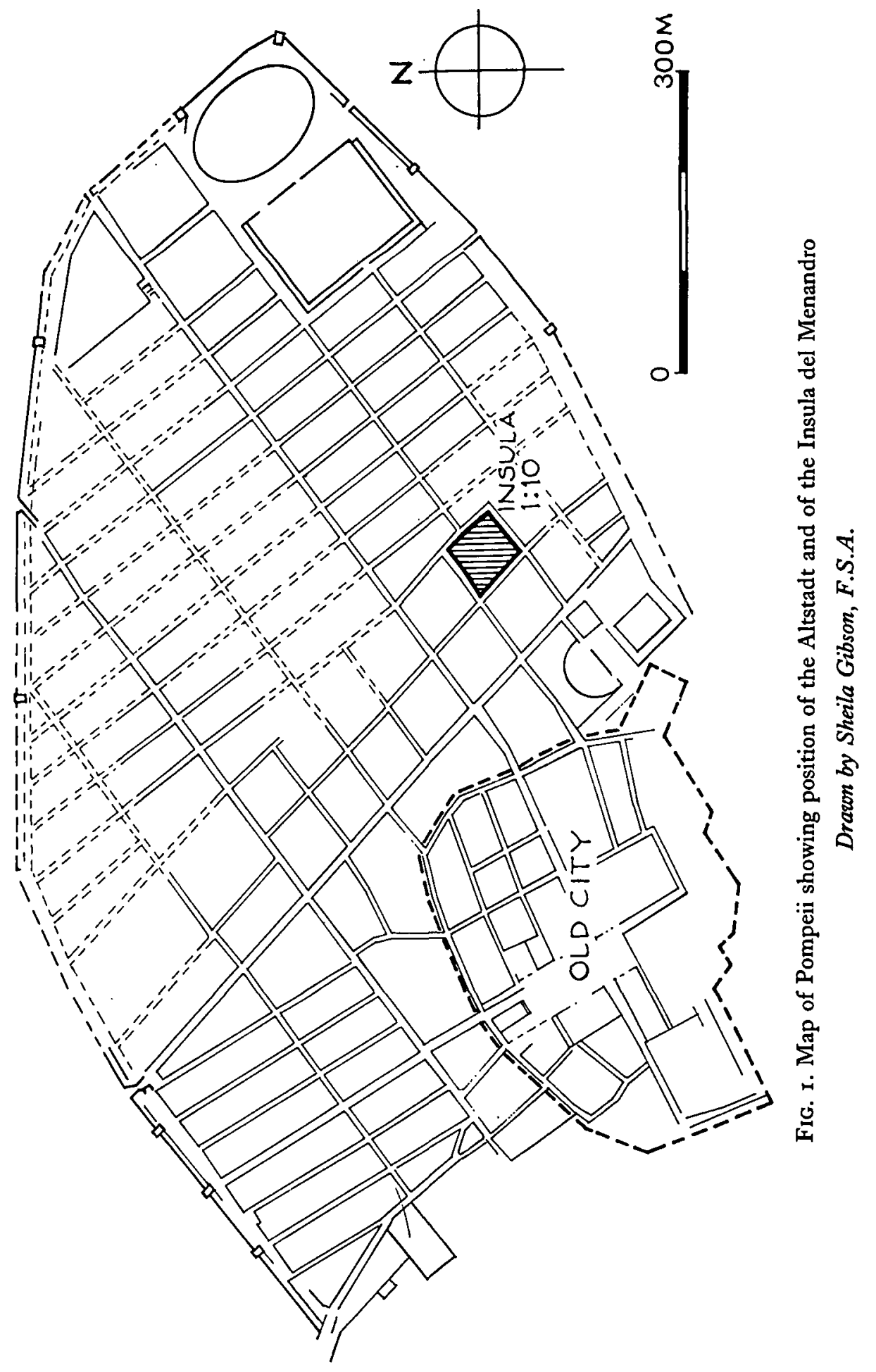


the form of the insula was partly dictated by suburban development which took place before the enlargement of the city, but in all probability the actual lay-out of this quarter belongs to the immediately succeeding period, that is to the early fourth century B.c. The more rigidly planned eastern quarter will have been laid out somewhat later. ${ }^{2}$

Whatever the date of the insula, it is not certain that any of the visible structures goes back to the first building phase. The dating of Pompeii's domestic architecture is notoriously difficult, and all we can say is that the earliest visible remains in I ro belong somewhere between the early fourth and late third centuries.

The land within the insula originally sloped fairly steeply from north to south (the difference of level along the west façade is $2.40 \mathrm{~m}$.), as did that in all the neighbouring insulae (e.g. I 6 to the north). That the buildings originally followed the slope is vividly demonstrated by the presence of walls and pavements of an earlier house partly exposed about $2 \mathrm{~m}$. beneath the floor of the large oecus (room I8) of the Casa del Menandro. It seems that at some stage, or rather in two or three stages, beginning perhaps in the third quarter of the first century в.C., the owner of the Casa del Menandro terraced his peristyle and its adjoining rooms over the remains of earlier buildings so as to secure a fairly level area for the main part of his house. The level drops abruptly about $2 \mathrm{~m}$. to the Casa degli Amanti, which preserves the old level in the south-west corner of the insula (fig. 3 ).

Apart from the structures under the Menandro oecus, virtually all the walls exposed by the excavators were those which were visible at the time of the fatal eruption in 79. At this stage about three-quarters of the insula was occupied by the Casa del Menandro (I ro, 4) and its dependencies (fig. 2). Opening from the north, the grand 'display' part of the house, with its axial sequence of fauces, atrium, tablinum and peristyle, occupied the central core; to the west of the peristyle lay a small bath-suite, which was undergoing alterations at the time of the eruption, and a kitchen area approached by an L-shaped corridor; and in the whole south-east quarter, again approached from the peristyle by a corridor, but also accessible by three entrances from the street to the east, was a service-quarter incorporating a yard and a stable. The remaining three corners of the insula were occupied by minor houses: the Casa degli Amanti (I IO, II) at the south-west, the Casa del Fabbro (I IO, 7) and another small atrium-house (I I0, 8) at the north-west, and three rather irregular houses (I 10, I8; I IO, I; I IO, 3) at the north-east. Finally there is a small shop-complex bestriding the adjacent angles of the Casa del Menandro and the Casa del Fabbro (I Io, 6).

The Casa del Menandro and its dependencies were published in a lavish monograph by Maiuri in 1933, though with more attention paid to the decorations and portable finds, especially the silver hoard found in a cellar under the bath-suite, than to the architectural development. ${ }^{3}$ The minor houses were published separately in a long article by Olga Elia in Notizie degli Scavi (1934); but again the approach is primarily descriptive rather than analytical. 4 There is no overall study of the insula and, although Maiuri sketched broad phases for the Casa del Menandro, nothing analogous has been done for the other houses. Only by analysing all parts of the insula in their relation to each other can we hope to comprehend something of the complex changes of property boundaries and building plans which took place.

\section{Methods of Analysis and Dating}

The main methods used in the analysis so far are, firstly, the study of building materials 
(8)
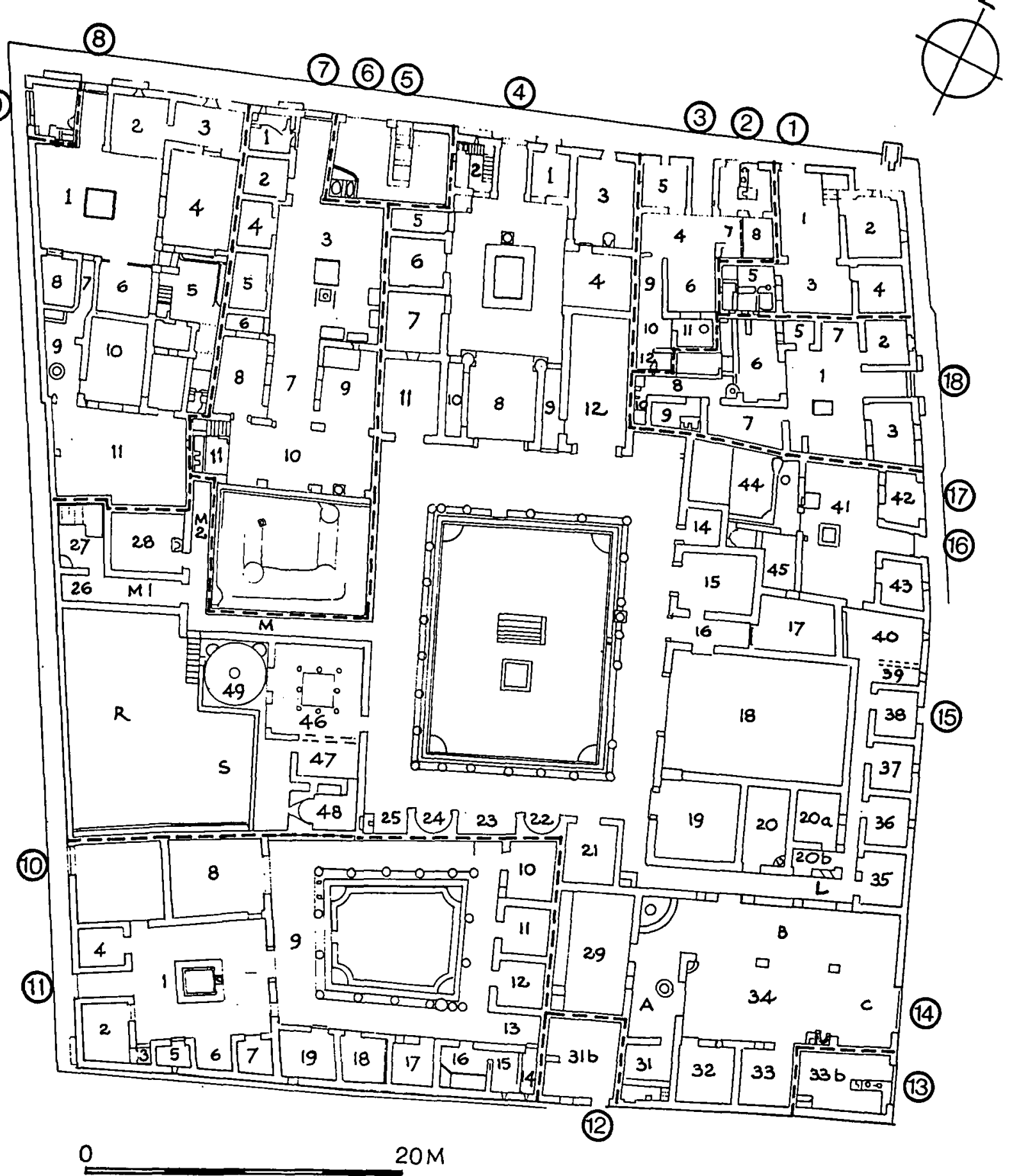

Fig. 2. Plan of the Insula del Menandro showing the property boundaries of A.D. 79 and the modern house- and room-numbers

Drawn by Sheila Gibson, F.S.A. 
and techniques and, secondly, the interpretation of wall-abutments and anomalies in plan. These require no special explanation here. A serviceable account of Pompeian building techniques is that of R. C. Carrington in his article 'Notes on the building materials of Pompeii', published in $1933 .{ }^{5}$ Briefly summarized, the earliest technique found in insula I Io, datable roughly to the fourth and third centuries B.c., is opera a telaio ('post-andpanel work') in the so-called 'Sarno limestone', a yellowish-white calcareous rock riddled with the imprints of shells and vegetable matter (pl. v). This gave way during the third and second centuries to mortared rubble construction with a facing of opus incertum, made with both Sarno limestone and dark grey lava (pl. vib, at the right). At the same time the brown or grey tufo (tuff) from Nocera (ancient Nuceria) was introduced for carved detail and ashlar façades. Opus reticulatum, first in grey lava, then in Nucerian tufo, came in after the founding of the Roman colony in 80 B.c. (pls. Ix $b$, xia). The use of broken tiles or bricks for quoins, though attested in public buildings as early as the first years of the colony, became widespread only from the Augustan age onwards (pls. vi $b$ at the left; $\mathrm{Ix} b$ ). The final main building technique, opus listatum ('block and brick work'), ${ }^{6}$ was introduced early in the first century A.D. (pls. vIII, $\mathrm{x} b, \mathrm{x}, \mathrm{xII} a$ ).

To refine the dating of individual phases of construction we can refer to other aids, notably interior decoration: i.e. wall-painting and to a lesser extent mosaic and other pavements. Wall-paintings naturally provide a terminus ante quem for the structures to which they are applied, and the successive styles of painting and their subdivisions are now well dated, especially during the period from the foundation of the colony to the mid-first century A.D., thanks to the work of Beyen, Bastet and De Vos. ${ }^{7}$ Paradoxically, however, wall-paintings can complicate matters by concealing the fabric of the walls beneath and hindering the interpretation of earlier building phases. This is especially true in large parts of the Casa del Menandro.

A further potentially valuable dating criterion, much neglected in the past, is pottery embedded in the fabric of the wall. Care has to be exercised to determine whether the pottery is part of the original construction rather than an addition at the time of patching, repointing or resurfacing (potsherds were used to provide a key for plastering); but a sherd incorporated in the structure of the wall may afford a terminus post quem, even a fairly close date. Among interesting items observed so far are a fragment of an imported amphora (Dressel 20, from Spain, not found in Italy before the end of the first century B.c.) and a sherd of terra sigillata (possibly of Puteolan manufacture and datable between Augustus and the third quarter of the first century A.D.), both in the south perimeter wall. The base of a Campanian black-'glaze' vessel $(c .300-c .3$ O B.C.) is visible on the surface of a wall in the Casa del Menandro stable-yard area. 8

Generally speaking, the task of phasing is difficult and uncertain. A major problem is that the tendency to reuse building materials in rubble construction and the frequent similarity of opus incertum walls erected at different periods make it hazardous to assign dates on general appearance. Conversely, building styles of varying appearance can occur in a single phase, for example quoins of both brick and opus listatum in a single development in Phase 4 B.

The plan in fig. 6 represents an attempt to codify the building techniques used in the insula. It is not interpretative save in minor respects: the symbols are not intended to correspond to chronological phases. Only in one case, the Phase 4 B development just 

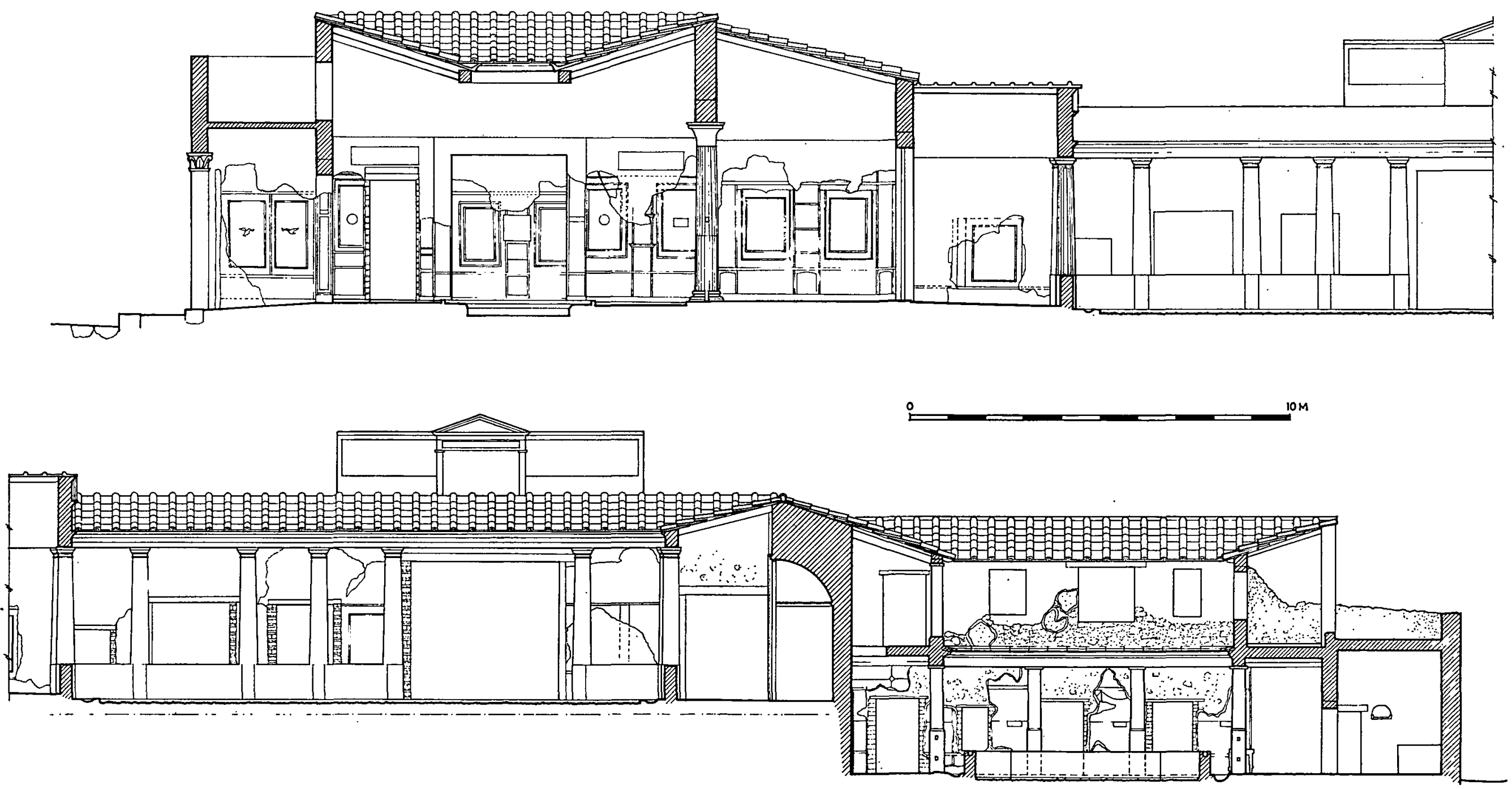

Fig. 3. Section through the insula from north to south

Drawn by Sheila Gibson, F.S.A. 

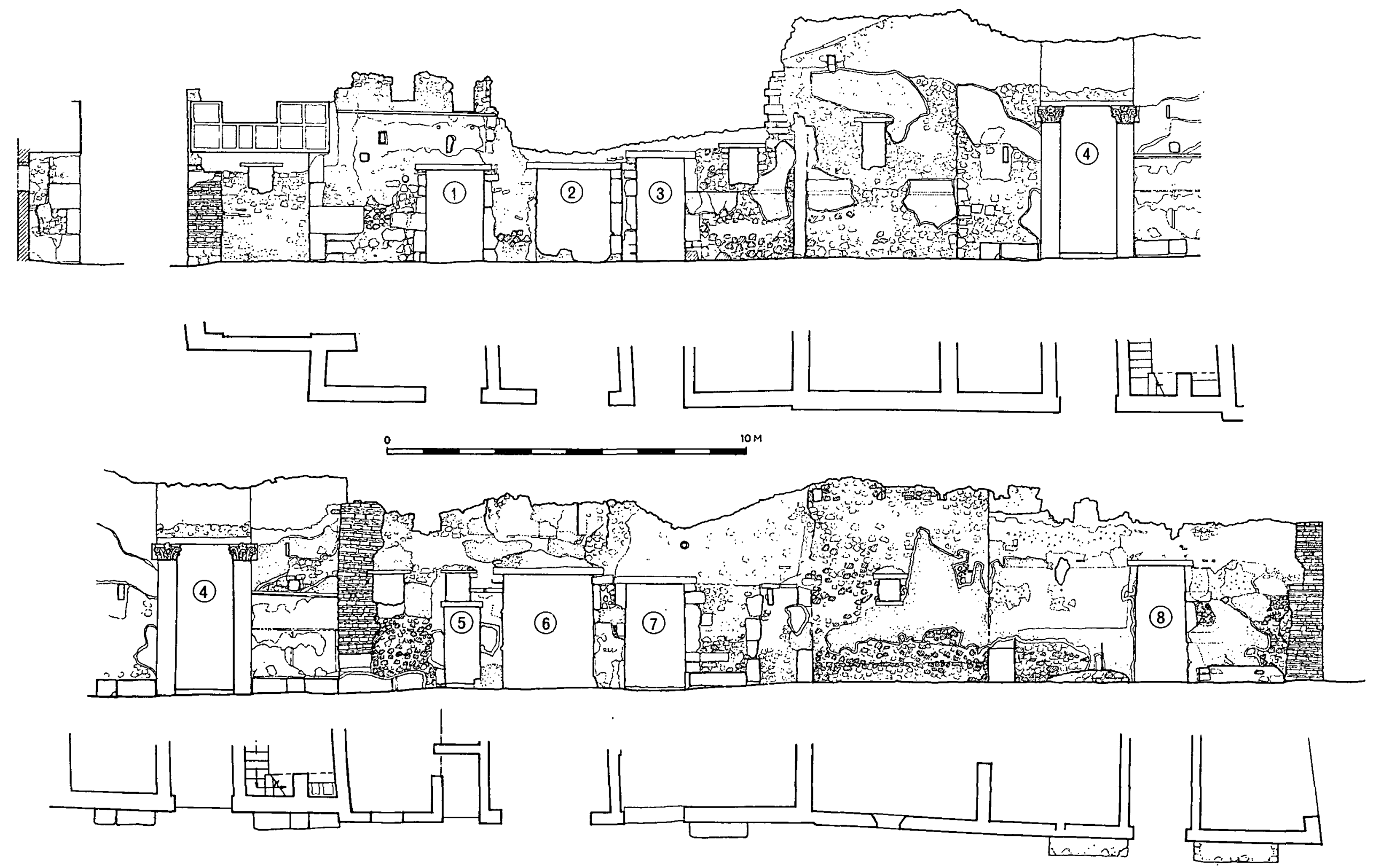

Fig. 4. Elevation of the north front of the insula

Drawn by Sheila Gibson, F.S.A. 

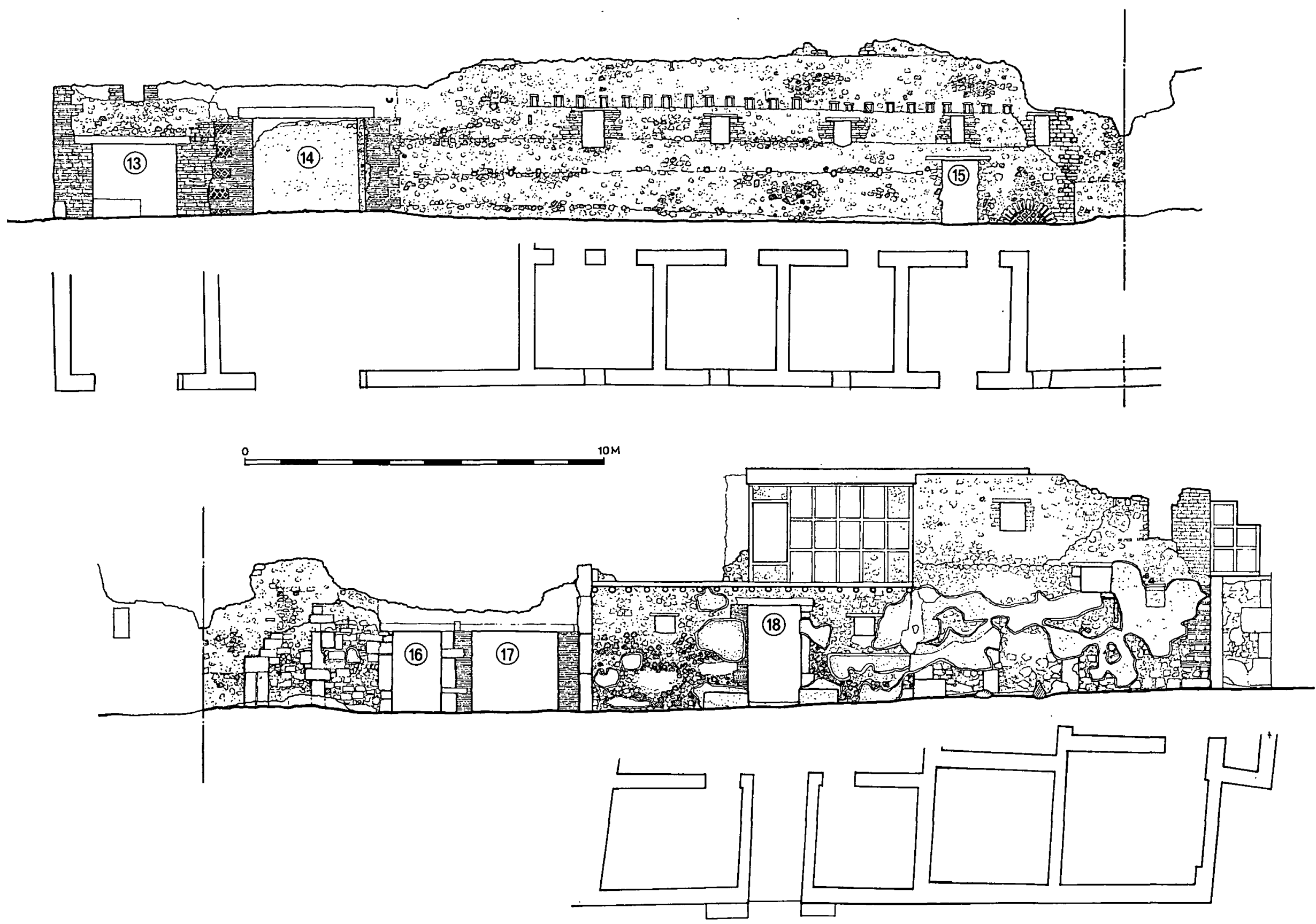

Fig. 5. Elevation of the east front of the insula Drawn by Sheila Gibson, F.S.A. 


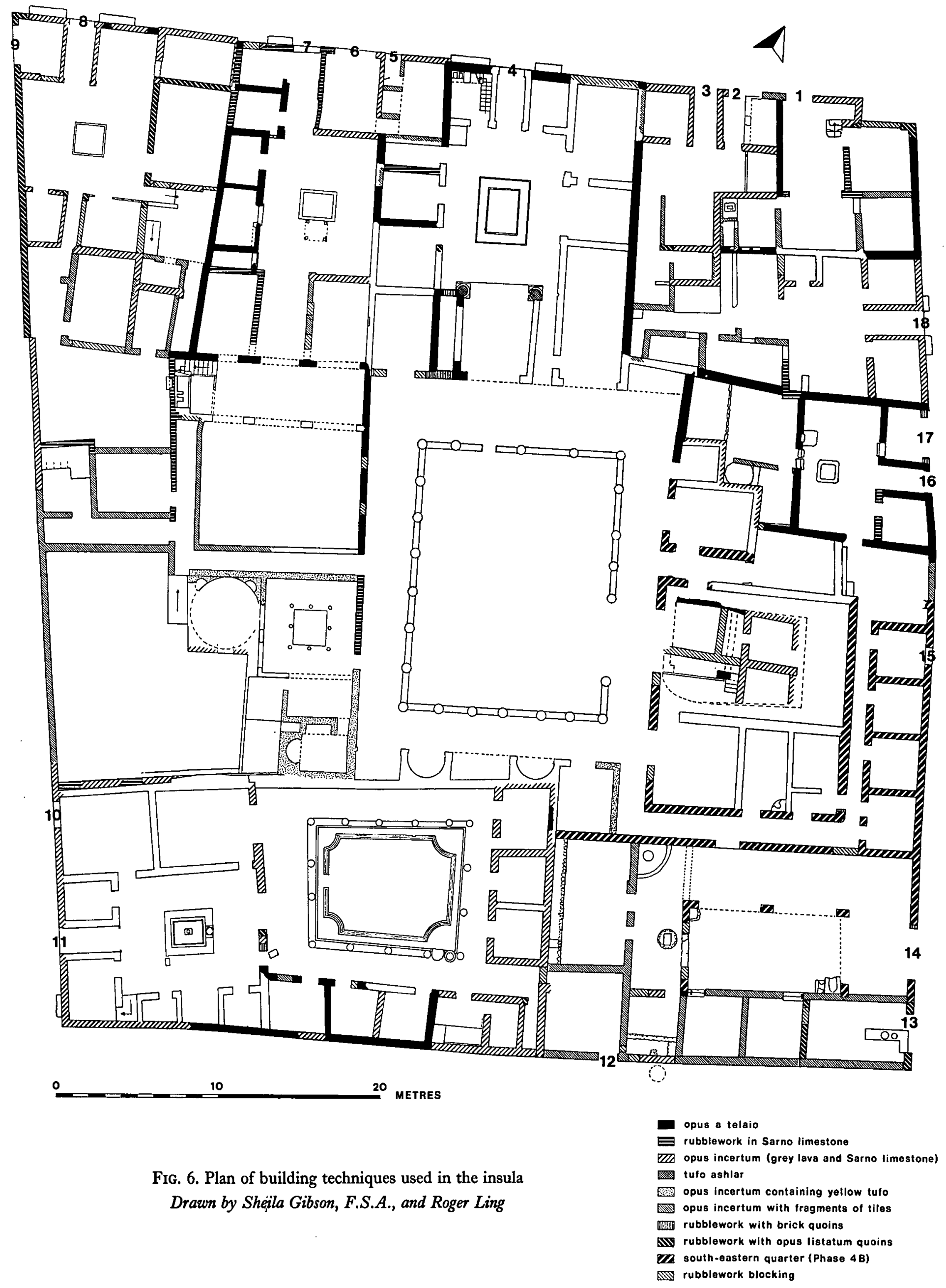


mentioned (the stable-yard area and slaves' quarters of the Casa del Menandro), is a separate symbol used for a building programme rather than a technical type.

Some general notes on the plan will suffice. It refers to the ground-level (i.e. the groundlevel of A.D. 79), the only exception being the structures discovered beneath the large oecus (18) in the Casa del Menandro. It should, however, be noted that some walls are visible at different levels on the two opposite faces, thanks to the raising of the level on one side during the history of the insula; and in such cases the lower level may reveal an earlier technique not visible on the other side. Where walls are covered by plaster, or are otherwise inaccessible, they have been left blank, except where the opposite face shows an early technique (e.g. opera a telaio) and we can therefore assume that the wall as a whole dates from an early period.

\section{INTERPRETATION OF Phases (figs. 7-12)}

On the basis of the criteria outlined above the history of the insula has been divided into five main phases, the first corresponding to structures in opera a telaio and related techniques, the second to the First Style of wall-painting (late third to early first centuries B.C.: structures generally in opus incertum with a preponderance of grey lava), the third to the Second Style of wall-painting (broadly the period c. 80-c. 20 B.C.), the fourth to the Third Style (the period from Augustus to the mid-first century A.D.), and the fifth to the Fourth Style (c. A.D. 50-79). Each of these phases is then subdivided as necessary.

Inevitably many question-marks hang over the early phases, especially where walls are masked by later plaster, or where structures have been destroyed or buried in later rebuilding (for example in the peristyle area of the Casa del Menandro and in the south-east quarter of the insula). Selective excavation might fill some of the gaps, but at the moment the early phase-plans necessarily contain large areas of empty space or fragments of unrelated walling. Only where there is some ground for predicting missing elements have parts of plans been restored.

It must be stressed that many aspects of the interpretation remain to some extent conjectural, and that it has not proved feasible, in the present context, to rehearse in detail all the relevant arguments.

\section{Phase I $A$ (early fourth to early third centuries B.C.) (fig. 7)}

The diagnostic features are the use of opera a telaio and inferences from the property boundaries and wall alignments. The irregular shapes of houses 3,7 and 16 imply that they have been inserted in the gaps between pre-existing properties; it is accordingly suggested that houses I, 4 and 8 belong to the earliest development in the insula. That house I originally extended backwards to include the front part of house 18 is implied by the more or less continuous alignment of its west wall and the walls at the back of the atrium of 18 , and by the salient angle encapsulated in the north wall of house 16 . In house 8 the blocking of an entrance door is visible opening into room 2 (cf. fig. 4); with its central position and Sarno limestone quoins, it probably belongs to the original plan, though the rest of the façade was rebuilt later. The backward extent of the house is indicated by the kink in the west wall of the insula (pl. via).

House 4, the Casa del Menandro, seems to have enjoyed some pre-eminence, with its 


\section{PHASE $1 \mathrm{~A}$}

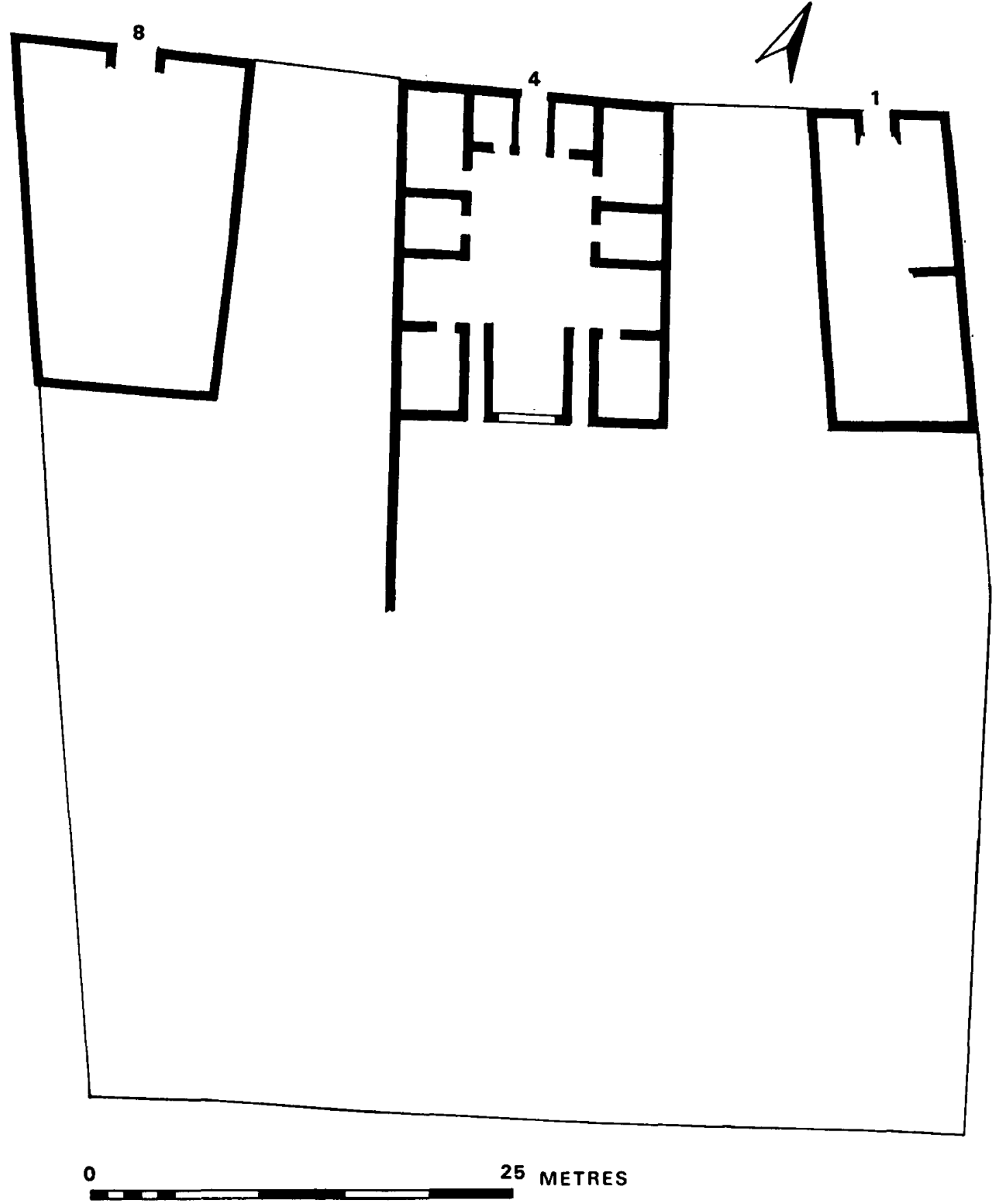

Fig. 7. Plan of Phase I A

Drawn by Roger Ling 


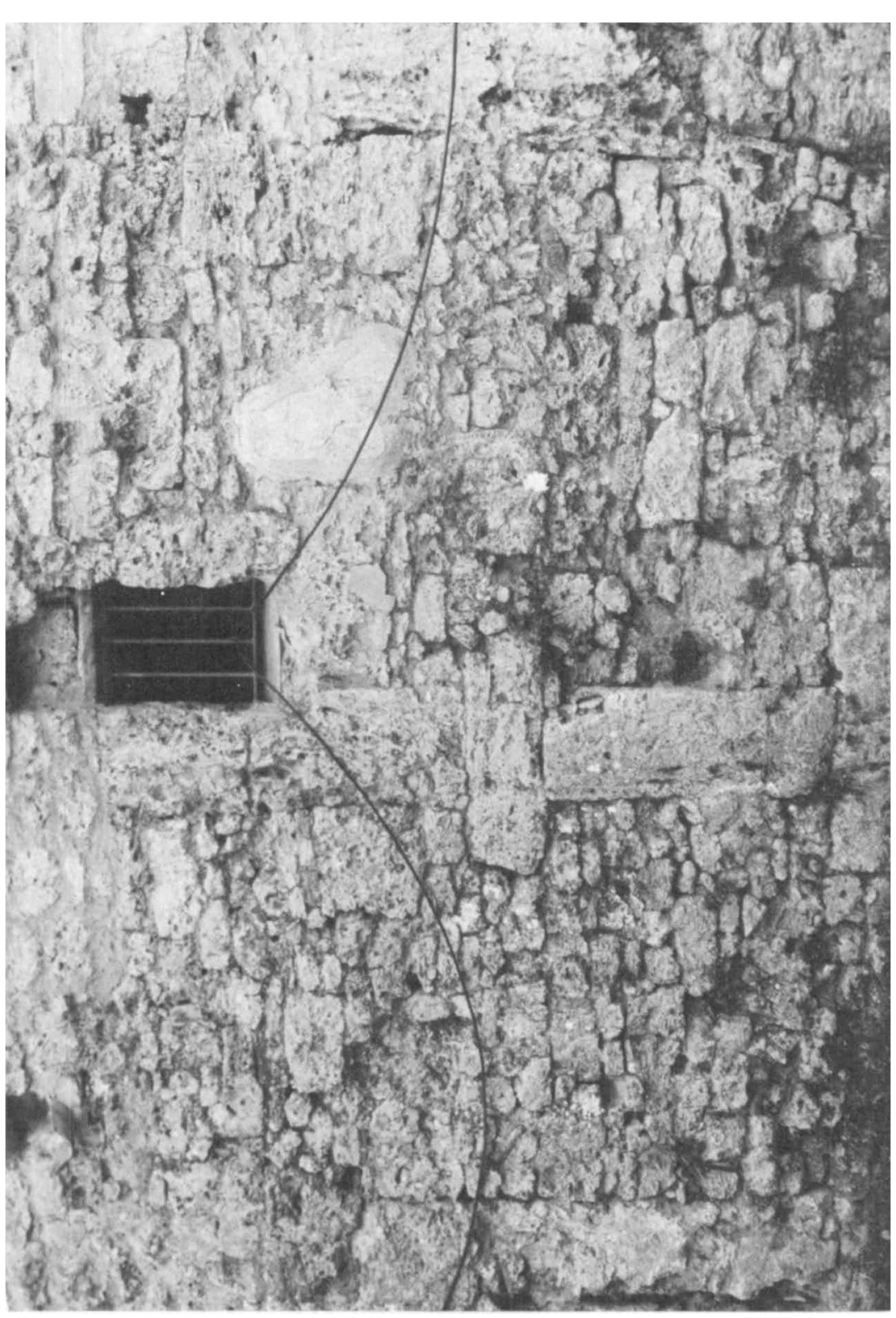

वें

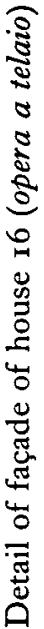




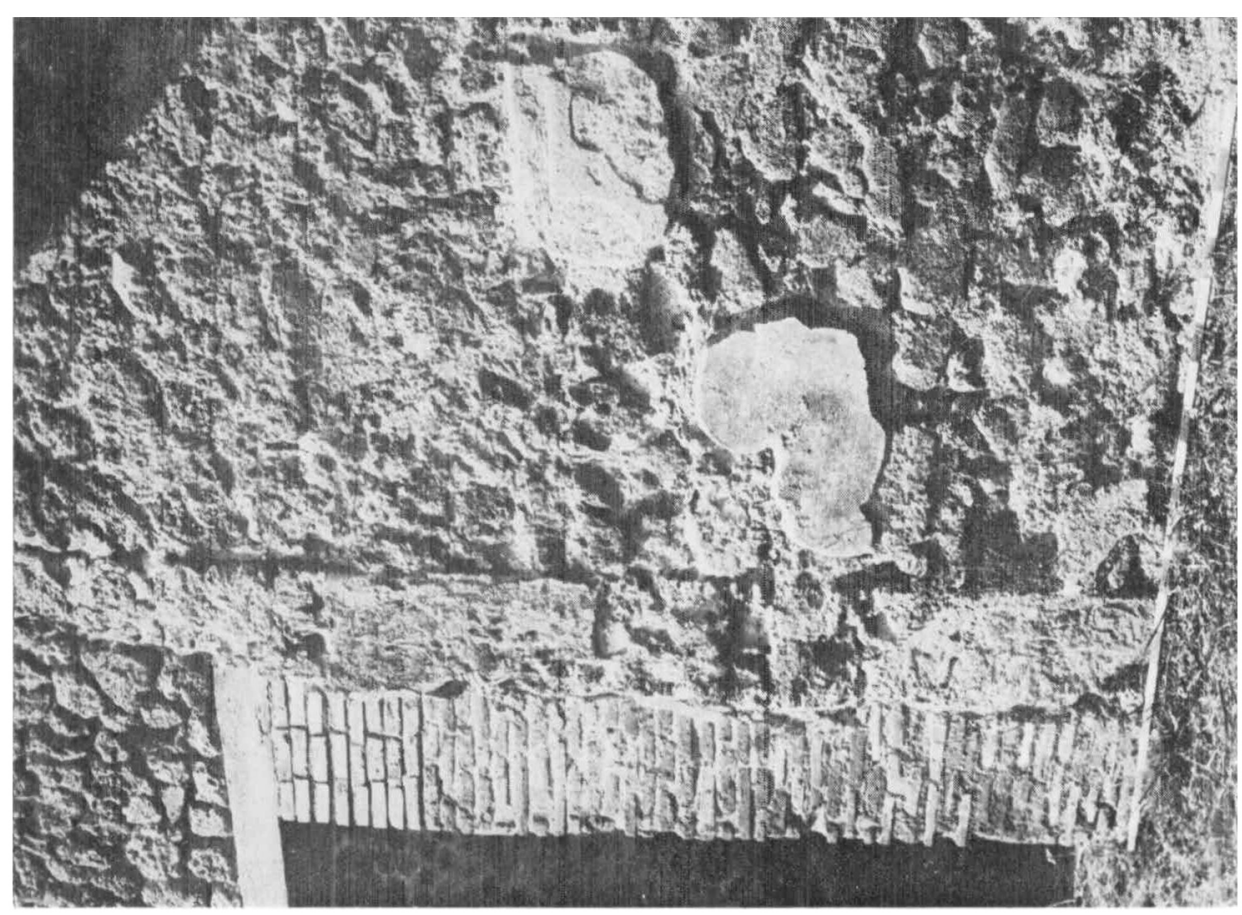

放

ฉี

范焉

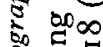

$8 \cdot$

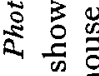

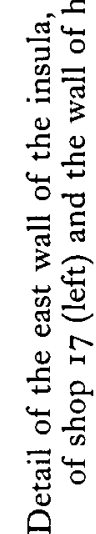

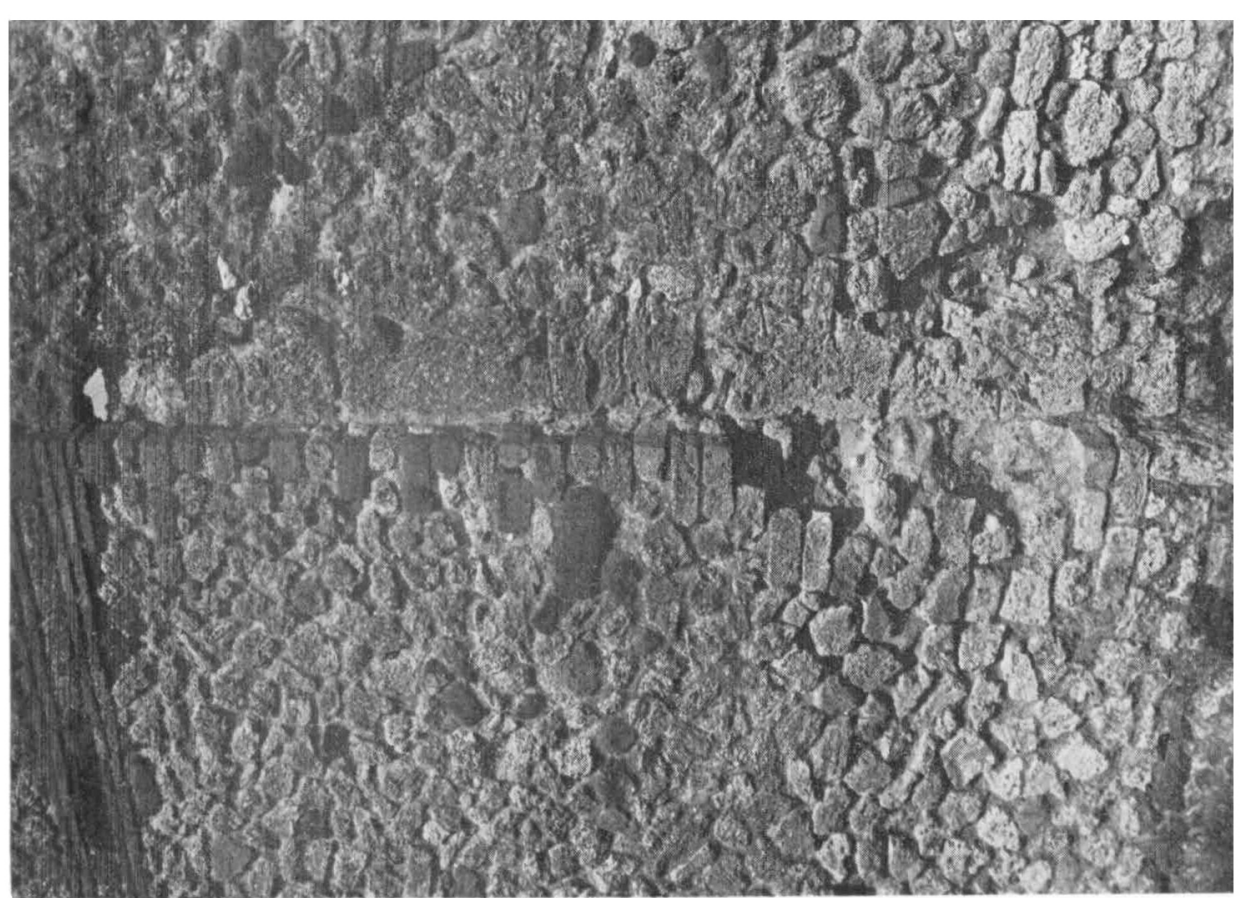

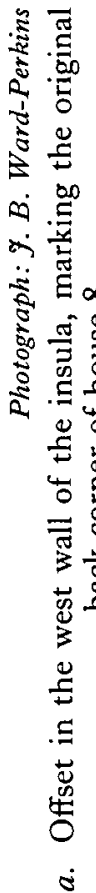



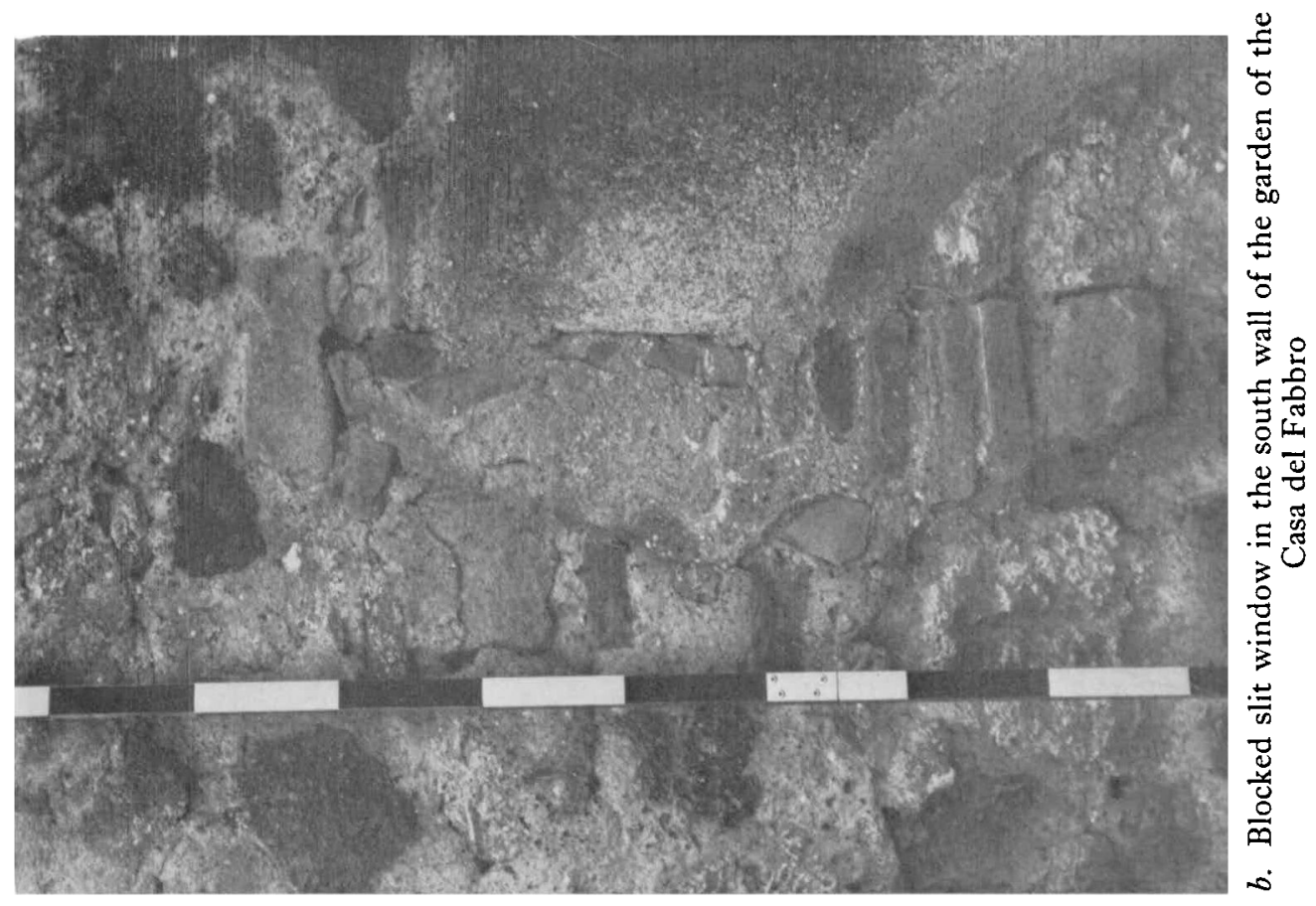

ن

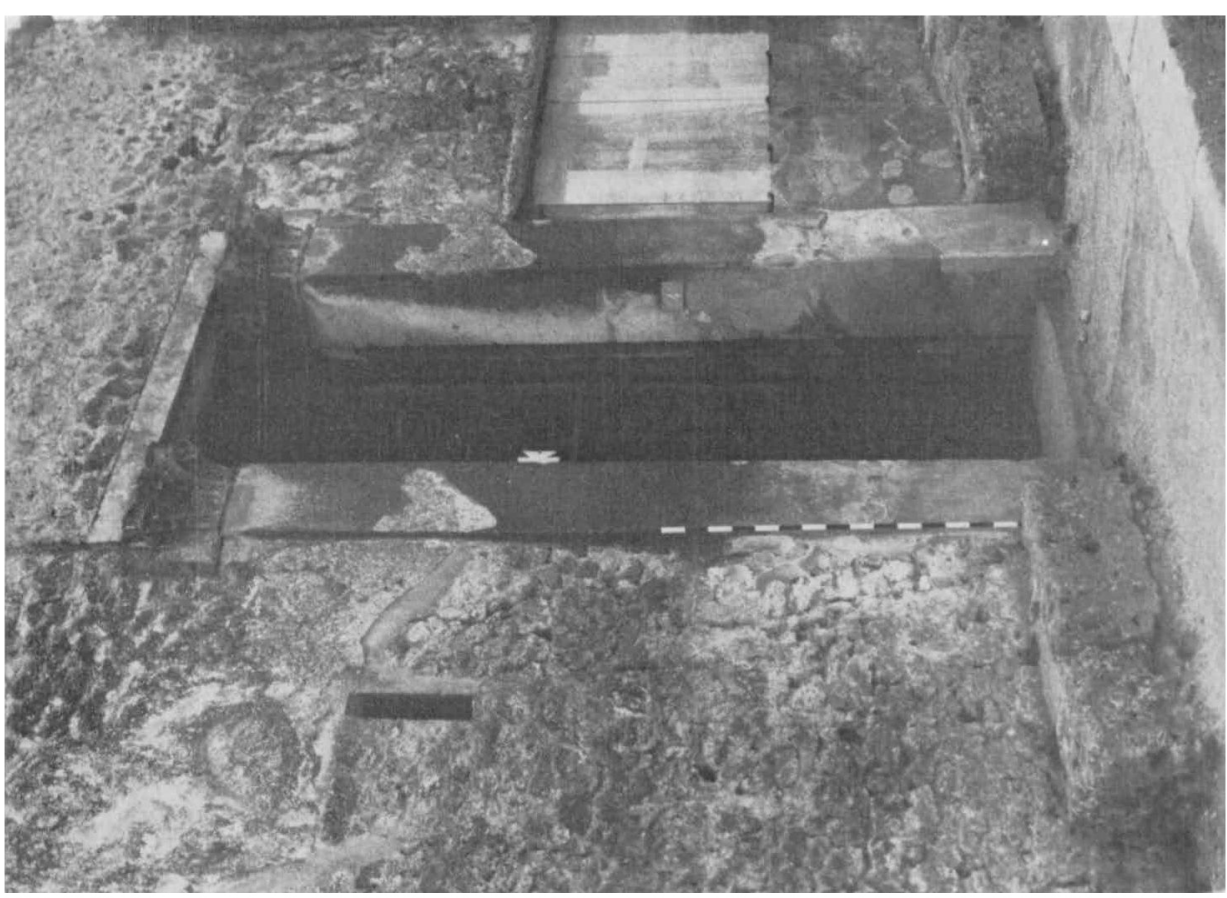

Ơ 


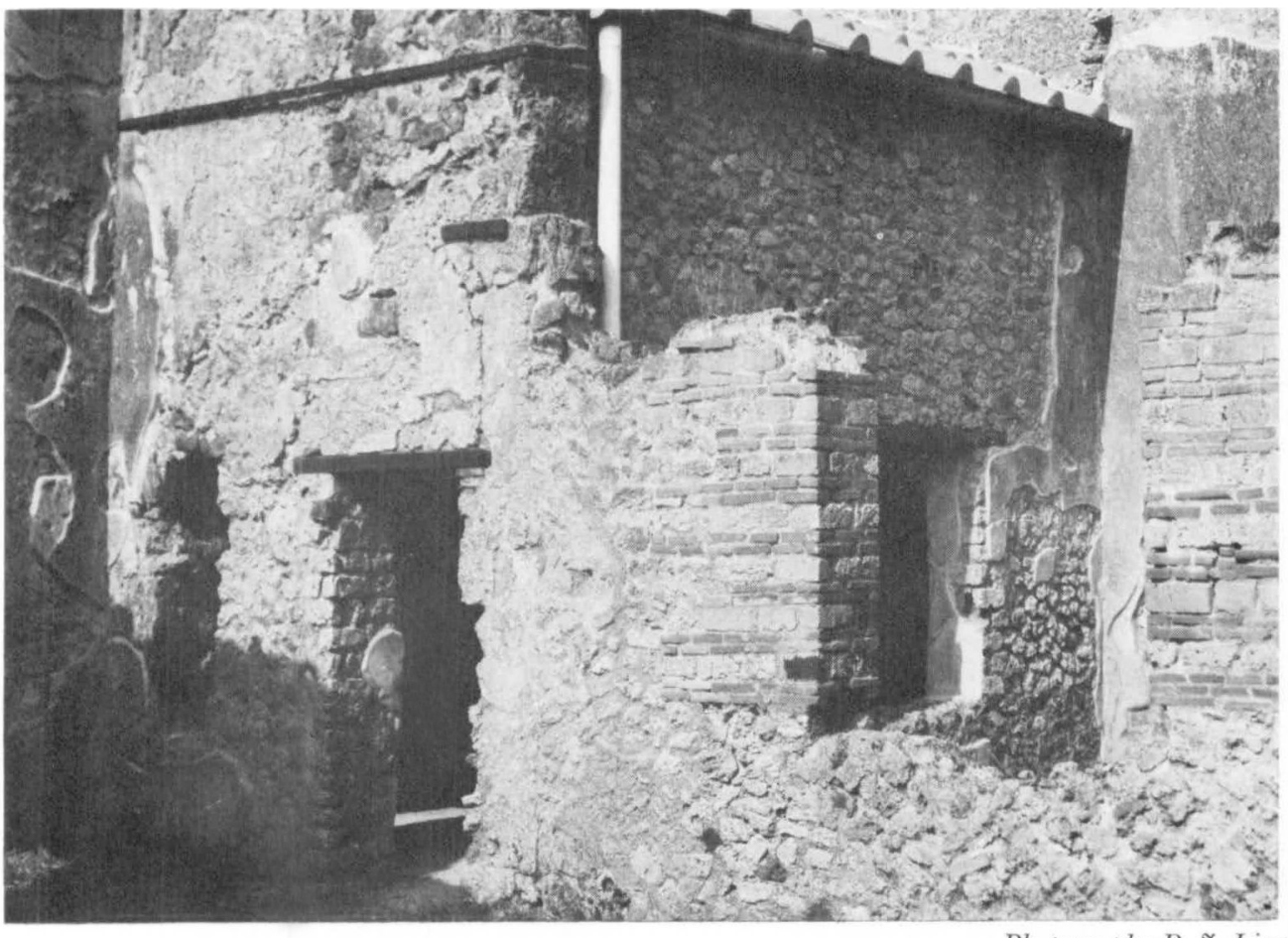

Photograph: R. F. Ling

a. East wall of the atrium, and door of room 3 in house 8

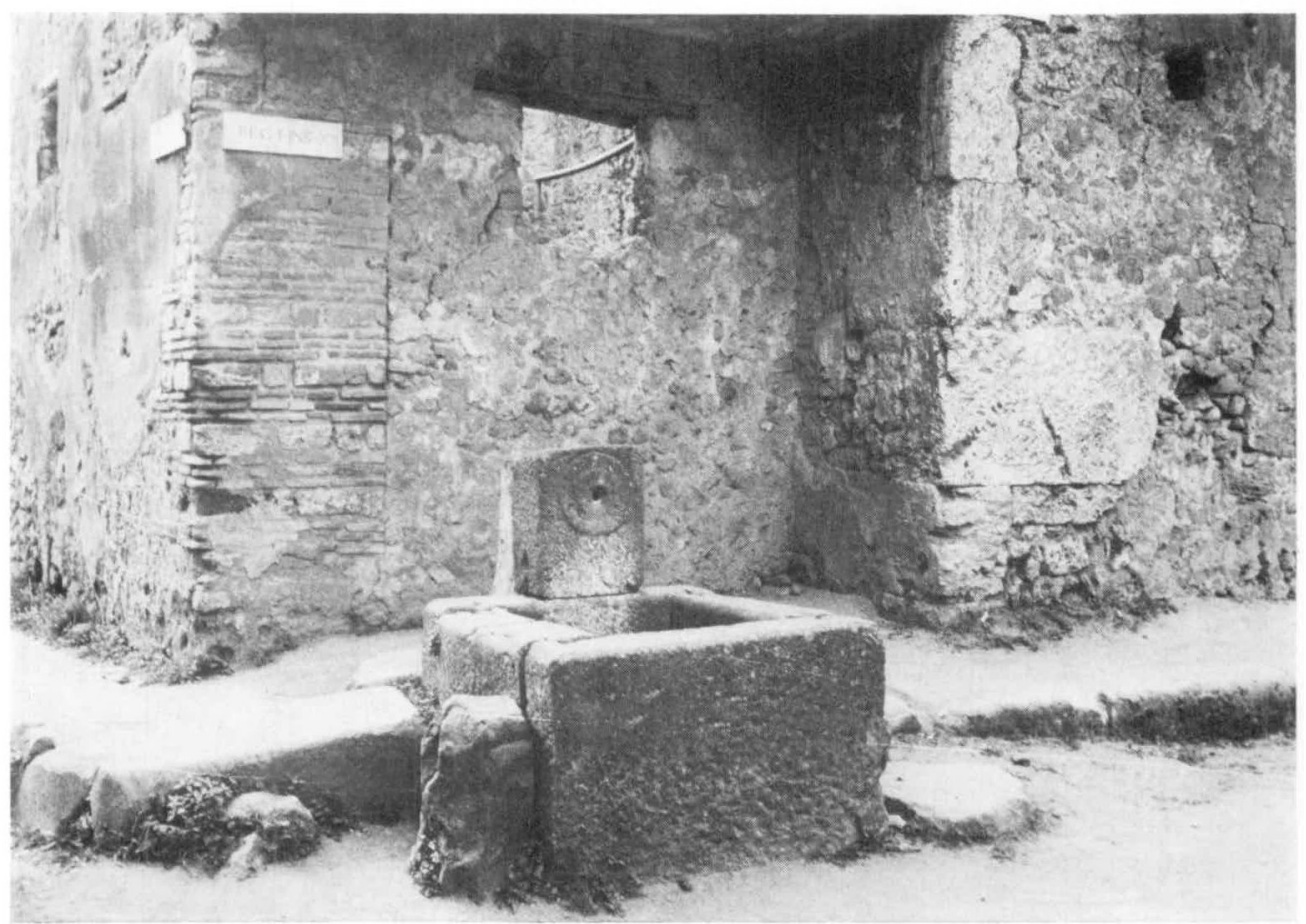

Photograph: F. B. Ward-Perkins

b. North-east corner of the insula showing street-fountain and blocked shop-opening in room 2 of house I 

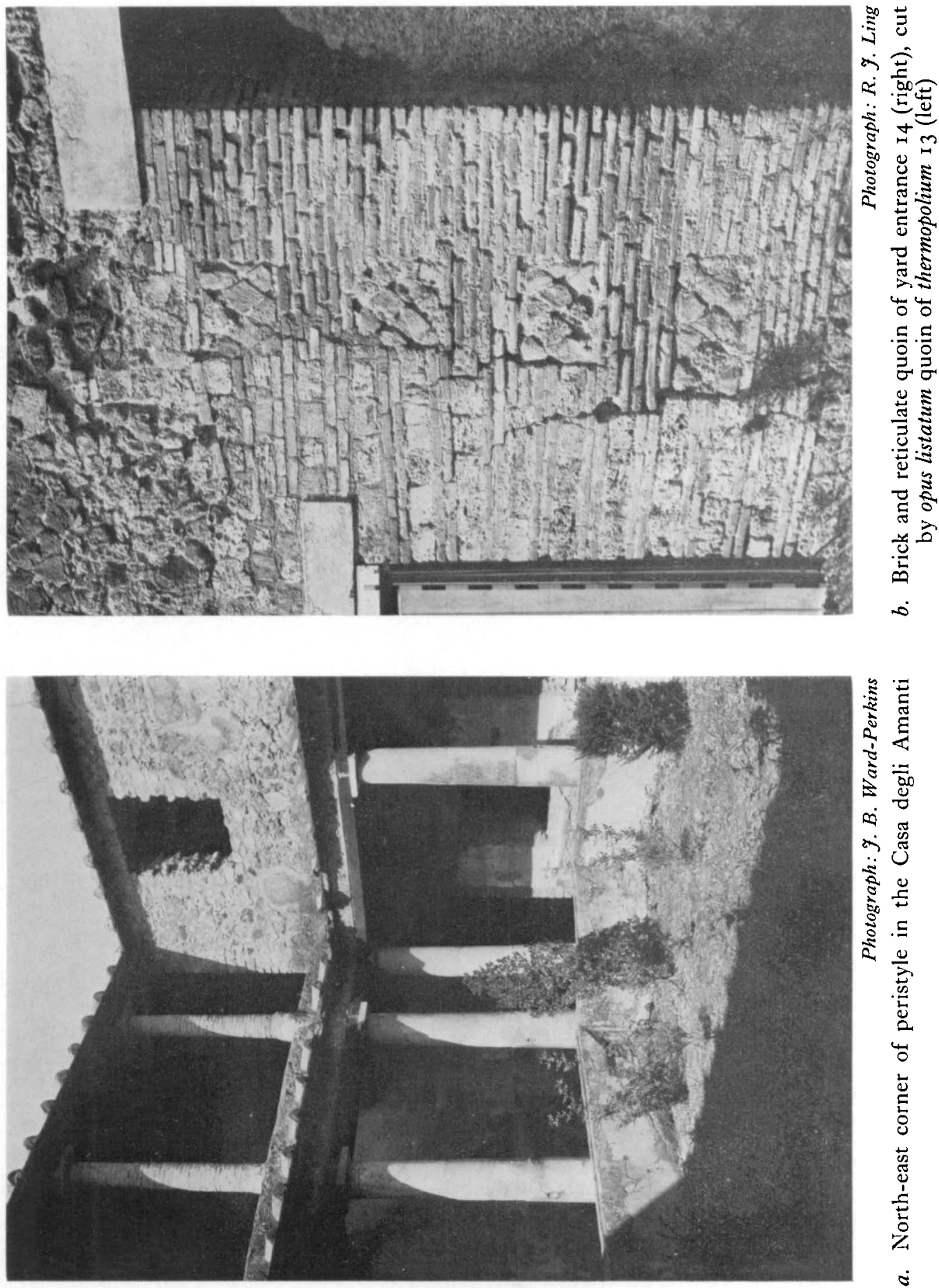


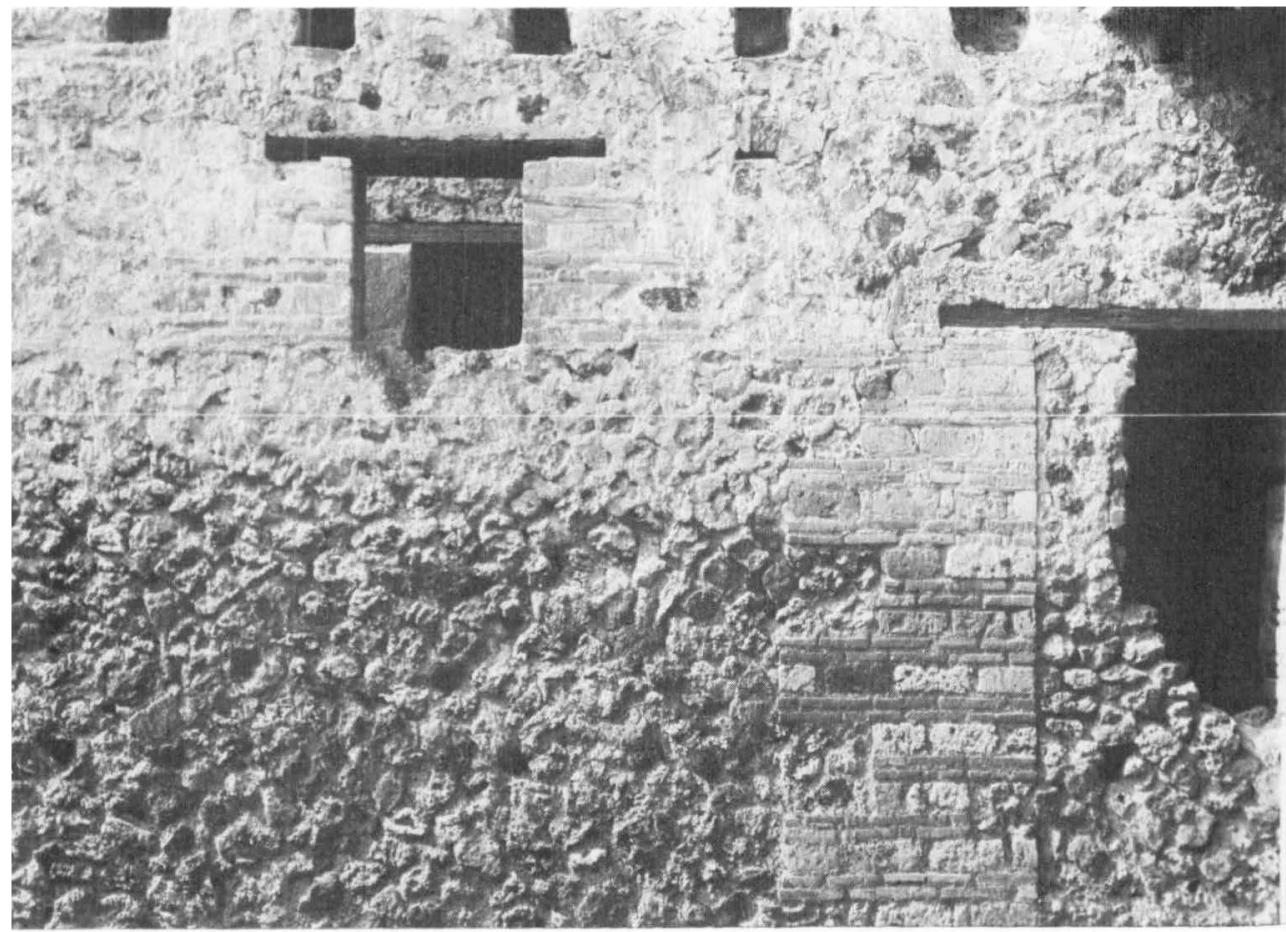

a. North wall of the Menandro stable-yard with blocked doorway at the right

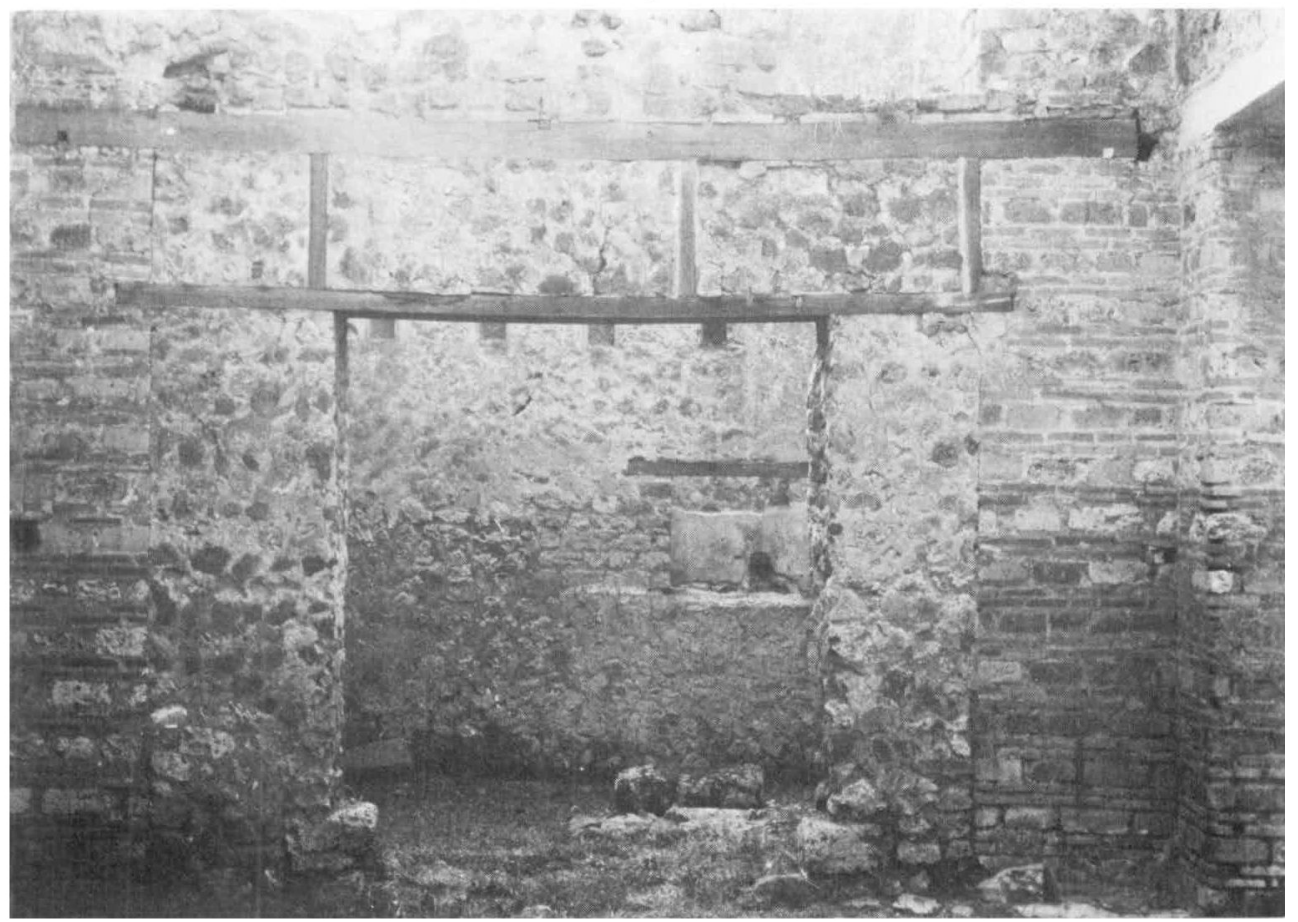

$b$. West side of the Menandro stable-yard, showing narrowed opening

Photographs: R. F. Ling 

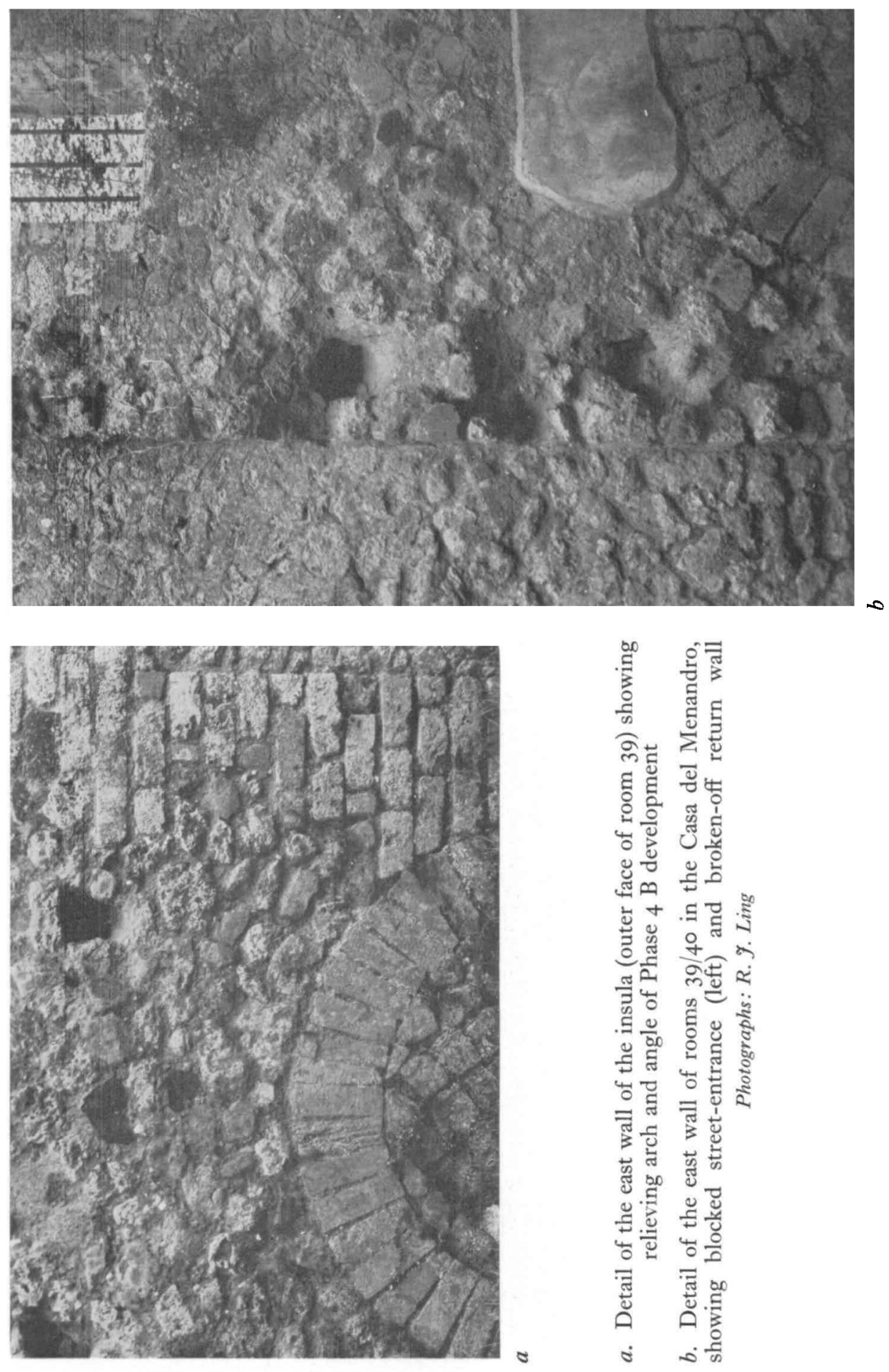

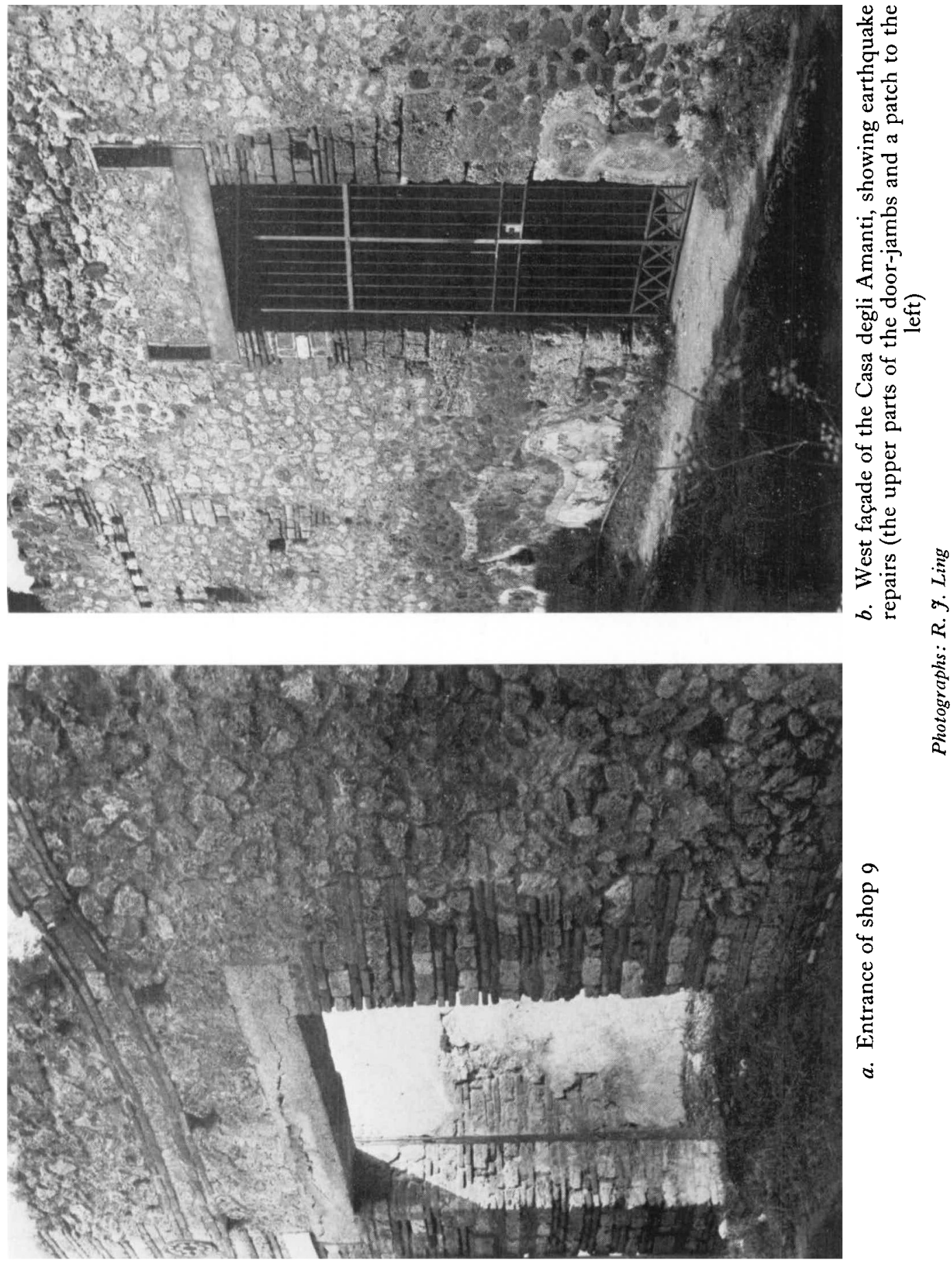
central position, broad façade, and apparently carefully laid-out plan (note the parallel boundary walls). It may already have extended further back than houses $I$ and 8 , since the west wall of the peristyle (construction of opera a telaio visible in the garden of house 7) prolongs the straight alignment of the boundary wall in the front part of the house. The existence of andrones (passages 9 and ro) also implies a garden or some form of development at the rear. The plan of the atrium complex has been restored as basically symmetrical, with the 'canonical' alae at the back of the atrium (compare the plans of the Casa del Chirurgo and Casa di Sallustio in region VI, both datable like the Casa del Menandro to the early Samnite period). That room 7 was originally an ala is suggested by the fact that its present east wall has quoins of opus listatum, implying structural conversion in Phases 4 or 5 (see below). Overall regularity is implied by the careful alignment of walls and the general feeling of architectural discipline pervading the house. Unpublished researches by Dr. Edith Evans on the atrium complex in the houses of Pompeii ${ }^{9}$ also draw attention to the correlation between the width of houses and the style of planning: greater formality of planning is found in houses which, like the Casa del Menandro, have space for two sideranges in the atrium complex rather than just one.

It is also suggested in the phase plan that the rooms at the rear of the side-ranges (II, I2) were at this stage turned towards the atrium rather than towards the rear of the house. This would again accord with the results of Dr. Evans's research, which suggest that such rooms normally began by facing towards the atrium and only later tended to turn to face the garden (whereas the tablinum often went through a reverse process, beginning as a thoroughfare to the rear and later being closed off). Here in room I I the brick piers flanking the opening to the peristyle are contemporary with the laying of the mosaic pavement and hint that the room had been turned towards the peristyle in Phase 3. An enlarged room I2, also facing onto the peristyle, may date to the same time or to Phase $5 \mathrm{~A}$.

It is interesting that the depth of houses $I$ and 8 and of the main part of house 4 seems to be more or less standardized (from 18.8 to $20 \mathrm{~m}$.). This is approximately 60 feet $\left(=\frac{1}{2}\right.$ actus), and it is possible that some sort of planning limit was laid down, whether by the city authorities or by the owner of the insula. It is possible that, since the Casa del Menandro apparently extended deeper than the other houses, its owner also owned the land behind them: the traces of one or possibly two blocked doorways on the west face of the wall dividing the Menandro peristyle from the later garden of house 7 could conceivably go back to this period.

\section{Phase I $B$ (third century B.c.) (fig. 8)}

It is suggested that the insula was fairly densely built up in this period. House 7 was inserted in the rather intractable space between 4 and 8 , with a back wall prolonging the property line at the rear of house 8 . Another property probably ran cross-wise behind both of them. House I6 (pl. v) was crammed between the back of house I and further properties to the south (now buried, though the earliest walls found in the excavation beneath the floor of the Menandro oecus may possibly belong to this phase). Maiuri suggests that the original rear wall of the atrium of house $\mathrm{i} 6$ was set back from its present alignment and the impluvium situated in the normal and logical central position; but there is no evidence that the present wall is not original, while the impluvium is probably late in date and 


\section{PHASE $1 \mathrm{~B}$}

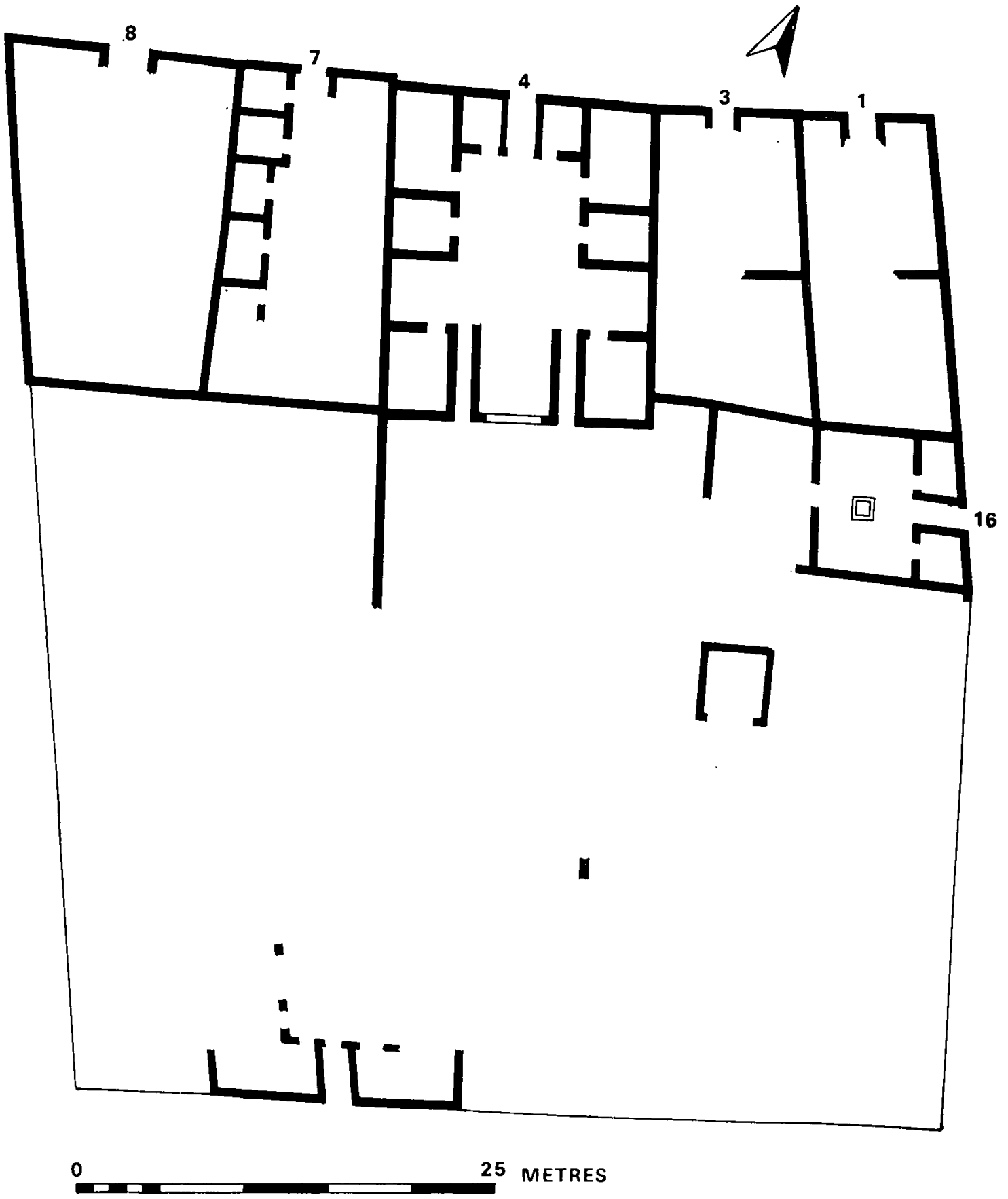

Fig. 8. Plan of Phase I B

Drawn by Roger Ling 
clearly non-functional. ${ }^{10}$ The atrium probably began life as a cross-hall without a roofopening. House 3 was perhaps now inserted in the irregular space between $4, \mathrm{I}$ and $\mathrm{I} 6$.

On the south side of the insula, the only trace of opera a telaio construction visible is the façade incorporated in the south exterior wall of the Casa degli Amanti. Certain elements of its front range can be recovered from traces in the walls of the rooms round the Amanti peristyle, but no further details can be restored. Part of a wall in opera a telaio is also visible at the back of the room at the north-east corner of the Amanti peristyle (room Io), but there is too little here to draw any conclusions on the early lay-out of the south-east part of the insula.

\section{Phase 2: First Style (late third-early first centuries B.c.) (not illustrated)}

This phase is the most difficult of all to isolate, partly because of the use of the anonymous opus incertum, partly because of the general replacement of First Style decorations at later dates. It is not, therefore, clear whether certain crucial changes are to be dated to this period or later: for example, the creation of house 18 from the back halves of houses I and 3 ; the opening up of houses 7 and 8 to the rear; or the building of rooms 14 and 15 on the Menandro peristyle.

But the two front rooms of house 3 (one of which, no. 2, was later converted into a taberna) were certainly created at this time; they were built in opus incertum, with grey lava preponderant in the exposed façade to the right of the fauces (fig. 4), and both retained traces of First Style stucco-work at the time of excavation. Room 5 also had a typical pavement for the period of the First Style: cocciopesto with a regular sprinkling of white tesserae. Whether the similar pavement in the tablinum (room 6) belongs to this period is less clear. ${ }^{11}$ If it did, this would imply that the rearrangement of property boundaries in this corner of the insula had already taken place, since its eccentric placing presupposes the existence of the kitchen area (5) of house $\mathrm{I}$, while its closeness to the fauces, which reduces the atrium area to a cross-space merely $2.7 \mathrm{~m}$. deep, suggests that the back part of the house had already been lost.

In house 8 the entrance was now moved to its present position. The fauces still retains fragments of a simple First Style decoration visible beneath a later layer of plaster. The former entrance area was turned into an oecus (room 2), which was again decorated with First Style stucco-work and had a cocciopesto pavement decorated with patterns of white tesserae.

In the Casa del Menandro the architectural details in Nocera tufo must, as Maiuri maintains, have been added in this period. He names the 'sofa' capitals of the main streetdoor (pl. vila), the three-quarter columns framing the tablinum opening, and three columns in the north arm of the peristyle. The latter, no longer identifiable because of modern restoration, would tend to confirm what one would expect: that the house now had a peristyle behind the tablinum. But the columns need not be in their original position, and the peristyle complex was certainly not as extensive as it later became, because the structures buried beneath oecus 18 contained First Style decorations and clearly continued in use throughout this phase, if not also through the next. It is possible that the Casa del Menandro now abutted against the north wall of these early structures, since such an arrangement would tally nicely with the indications of the probable southward extent of the tufo peristyle (cf. fig 9). The northern part of the peristyle has a tufo gutter as far as the 


\section{PHASE 3A}

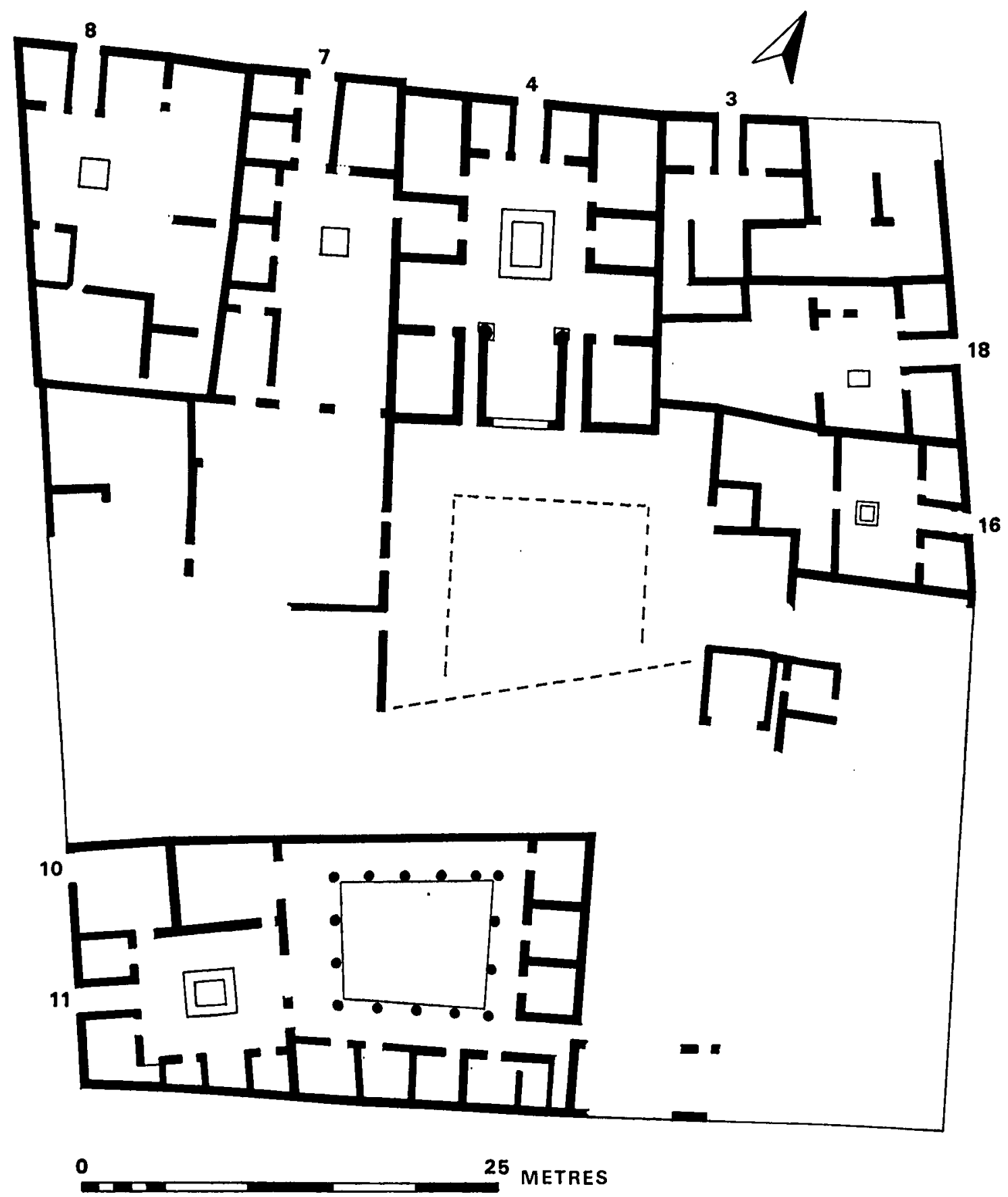

FIg. 9. Plan of Phase $3 \mathrm{~A}$

Drawn by Roger Ling 
fourth column in the east portico and the fifth intercolumniation in the west portico; beyond that the material changes to limestone (?) coated with opus signinum. It would seem that this opus signinum gutter and the corresponding part of the peristyle belong to a later extension, presumably that of Phase $3 \mathrm{~B}$.

\section{Phase 3 A: Second Style (c. 50-40 B.c.) (fig. 9)}

The main event of this phase was the construction of the Casa degli Amanti in the southwest corner of the insula. Its date (c. 50-40 B.c.) rests primarily on the Second Style wallpaintings of the fauces, but is corroborated in general terms by the profile of the impluvium, which belongs to Fadda's type $A_{3}$, attributable to the late Republican period. ${ }^{12}$ The house incorporates some of the walls of the Phase $\mathrm{I}$ house whose façade is visible in the south wall of the insula, but it runs cross-wise to that earlier house, with the main entrance opening from the street to the west (Vicolo Occidentale). The atrium complex is oriented on the alignment of the Vicolo Occidentale, whereas the peristyle complex, which opens immediately behind the atrium without an intervening tablinum range, is oriented on the south façade of the insula. The irregular form of the peristyle itself (trapezoidal with six columns in the northern arm as against five in the southern) is conditioned by the divergent angles of the atrium complex to the west and the property boundary to the north (the latter presumably respected pre-existing alignments). The level of the house is roughly analogous to that of the remains buried beneath the floor of the Casa del Menandro oecus 18 , and is about $2 \mathrm{~m}$. below that of the Menandro peristyle, which was probably not yet laid out in its present form (although the lay-out of rooms $13, I_{4}$ and I 5 at its north-east angle may already have been fixed).

It is assumed that the Casa degli Amanti was built more or less in what was to be its final form, apart from the upper storey of the peristyle. At this stage it was linked by a back entrance at the end of passage 13 to the area to the east.

It is also likely that the Casa del Menandro had by now been united with house 7 to form a double-atrium mansion of a kind attested elsewhere in the city in the second and first centuries B.c. (e.g. Casa del Fauno; VI 7, 20-2I; VI 8, 20-22; I 6, 2-4).13 That the two houses were at some stage connected is revealed by a blocked doorway visible in the west wall of Menandro room 6 and a blocked window in the east wall of the atrium of house 7 . It would also help to explain how it was possible later to create the shop-complex 5-6 out of the adjacent front corner-rooms of the two houses. That the houses had originally been independent is shown by the apparent lack of co-ordination between their lay-outs, and especially between the back of their tablinum ranges. It is, of course, impossible to know the circumstances which led to the merging of the two properties under single ownership, but a suitable occasion may have been the planting of the Roman colony in 80 B.C. and the confiscations and changes of ownership attendant thereupon.

Phase 3 B: Second Style (c. 40-30 B.C.) (fig. 10)

To this phase is ascribed the laying out of the present peristyle of the Casa del Menandro and of the bath-suite in its initial form. The date is provided by the wall-paintings and stucco reliefs still preserved in parts of the complex (the semi-dome of the semicircular exedra 24, the walls of the rectangular exedra 25, the walls of the atriolum and tepidarium of the baths, the ceiling of the passage between the tepidarium and caldarium, and the apse 
PHASE 3 B

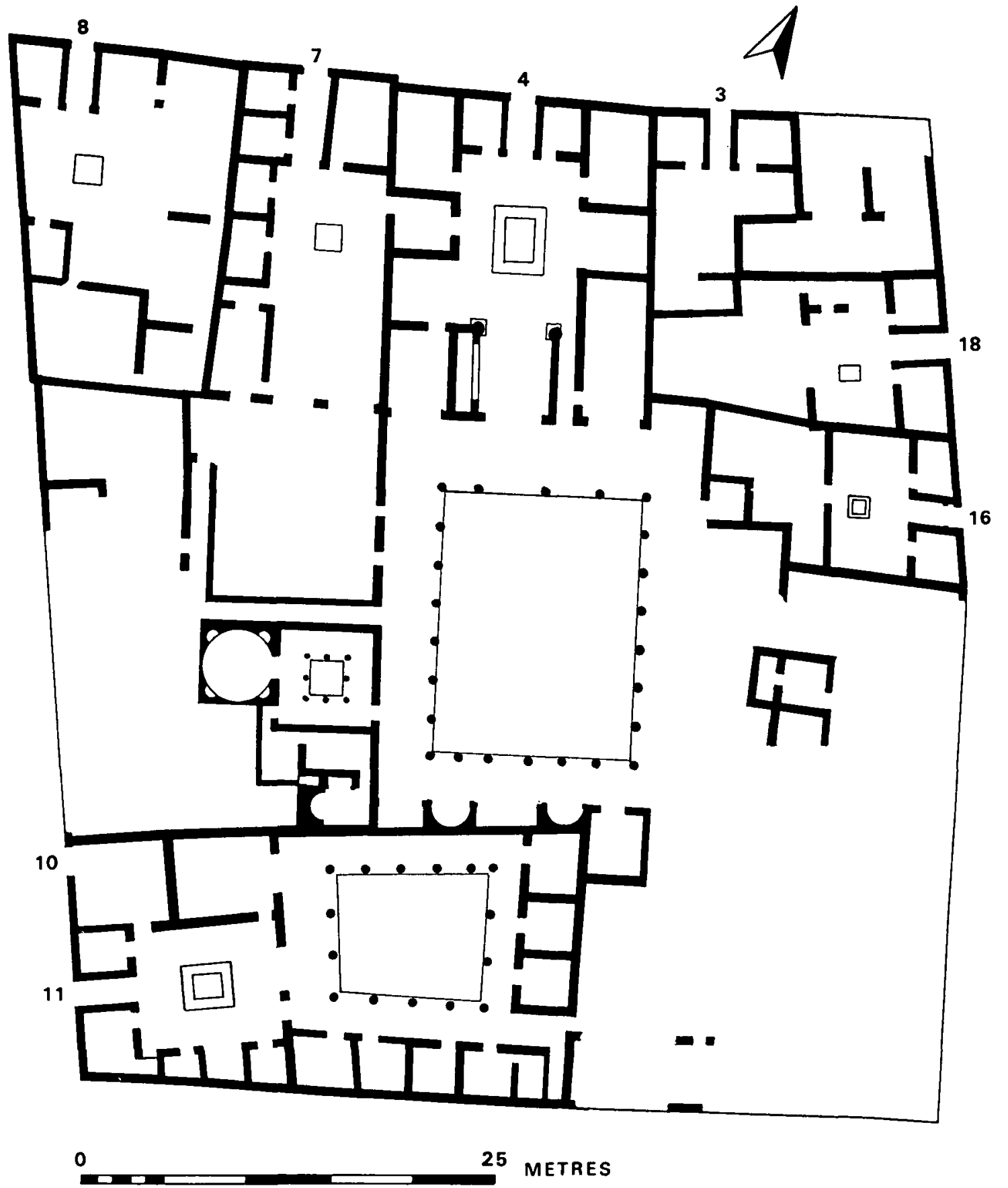

FIg. 10. Plan of Phase 3 B

Drawn by Roger Ling 
of the caldarium). The mosaic pavements of rooms II and 2I probably belong to this period, and so the opening up of room i I to the peristyle, with the insertion of brick jambs and the associated blocking of the andron Io, must also be ascribed to it. The present back wall of room 21 seems to be contemporary with the rebuilding of Phase 4 B, so we must assume that the original wall fell victim to the alterations of that period. This would account for the destruction of the back part of the mosaic.

The structures are carried out in opus incertum, the main innovation being the inclusion, apparently for the first time in the history of the insula, of the yellow tufo from the Campi Phlegraei, visible in the exposed parts of walls in the bath-suite and room 21. Otherwise the materials used are chiefly Sarno limestone and Nocera tufo. That the bath-suite, and therefore presumably the south wing of the peristyle, post-date the ground floor of the Casa degli Amanti, is indicated by the fact that the external west wall of the baths abuts against the north wall of the Casa degli Amanti and also overlaps a line of roof-tiles, which probably joined the original roof of the Amanti peristyle, immured in the same wall. The varying depths of the exedrae 22-25 are of course dictated by the need to reconcile a regular peristyle lay-out with the divergent line of the north wall of the Casa degli Amanti, while the division into alternating rectangular and semicircular forms is designed neatly to fit the space between the north-east corner of the Casa degli Amanti and the point where the prolongation of the Menandro west wall (i.e. the west wall of the peristyle) meets the Amanti north wall. Of the four exedrae one forms the visual culmination of the west arm of the peristyle, while the other three make a symmetrical group in which the central rectangular bay is placed more or less directly opposite the tablinum and is thus the focal point of the vista from the street door. Room 2I, at the east end of the south arm of the peristyle, is fitted behind the north-east angle of the Casa degli Amanti, another factor which implies the anteriority of the latter house.

What happened in the south-east quarter of the insula in this phase remains uncertain. Since the openings along the east side of the peristyle belong in their present form mainly to Phase $4 \mathrm{~B}$, and the present unequal spacing of the columns echoes these openings, the east colonnade has been restored with equal intercolumniations, the mirror-image of the west. ${ }^{14}$

The arrangement suggested for the baths is based on the assumption that the semicircular 'solarium' (room 49) was originally a circular laconicum of a type found frequently in bath-buildings of the first centuries B.C. and A.D. (Stabian Baths at Pompeii, villa at Varano, House of the Emperor Joseph II at Pompeii, Suburban Baths at Herculaneum), ${ }^{15}$ and on the observation that there was originally a solid wall between the atriolum $(46)$ and the tepidarium (47: Maiuri's 'apodyterium'), which was entered by a door in the west wall. Some elements remain uncertain: for example, there must have been a room (apodyterium?) in the re-entrant angle between laconicum and tepidarium, but its plan cannot now be recovered: the plan here postulated is designed to make the best use of the underlying walls.

The L-shaped corridor north of the baths may have been added in this phase. It shows that the owner of the Casa del Menandro now owned house 7 too (see above), as well as some land to the west of the baths. The corridor was lit by splay windows from the garden of house 7 (pl. vilb) and opened into the area now occupied by the kitchen (room II) at the north-west corner of the garden. Its purpose was certainly to provide access to the land behind the baths and possibly to serve rooms $26-28$, if these existed and formed part of the Casa del Menandro at this date. 
48

\section{PHASE 4A}

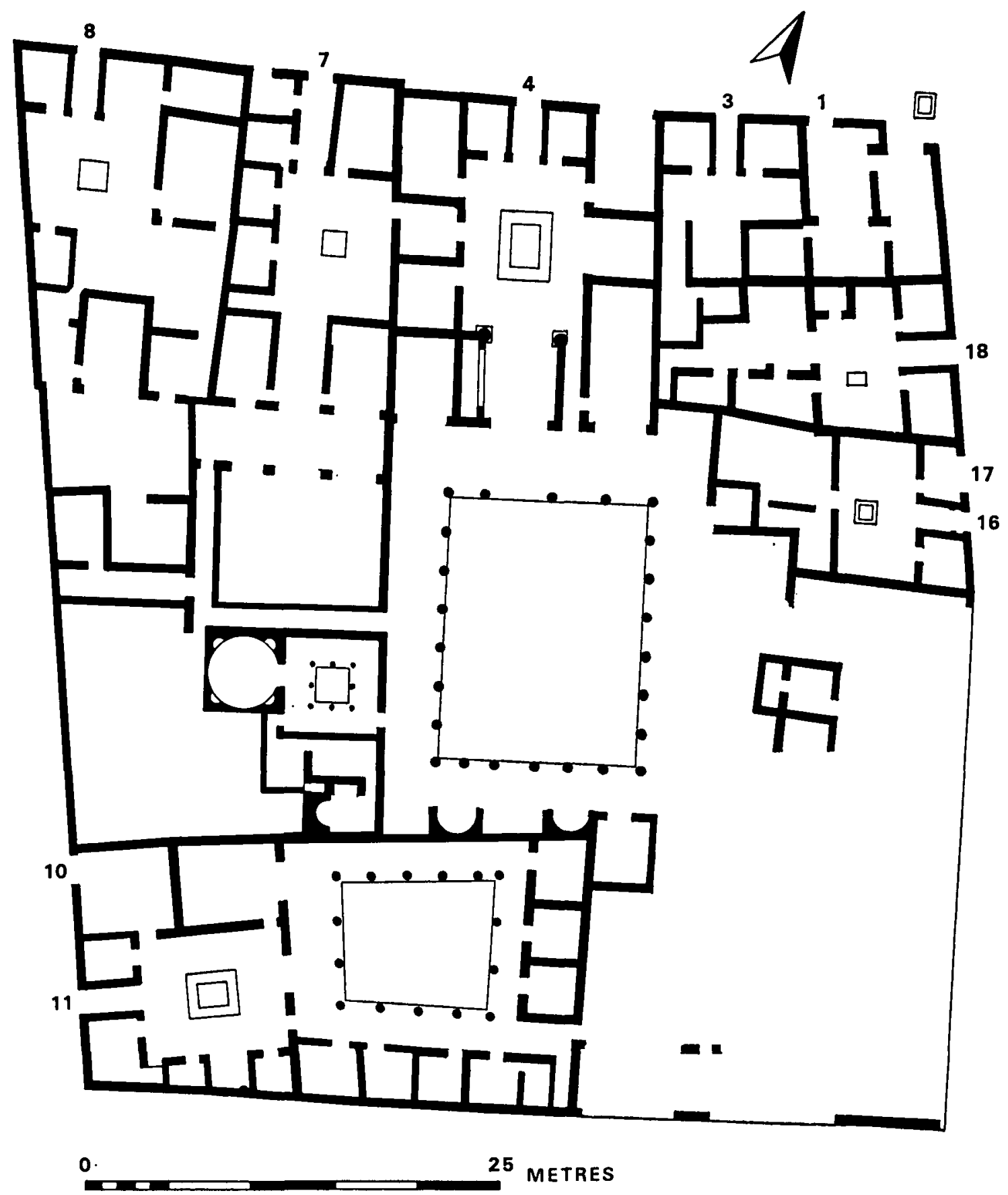

Fig. II. Plan of Phase $4 \mathrm{~A}$

Drawn by Roger Ling 


\section{Phase 4 A: Third Style (first half of first century A.D.) (fig. II)}

Various transformations can be dated on the basis of (mainly late) Third Style paintings: for example, the modifications on the east side of the atrium of house 8 , carried out in rubblework with quoins of opus listatum, probably at the time of the redecoration of room 3 (pl. villa); the creation of room ro in the same house as a large triclinium facing onto the garden behind (which was perhaps itself a creation of this period); the systematization in their final form of the 'atrium' and 'tablinum' in the tiny house no. $\mathrm{I}$; and the creation of the upstairs balcony, as well as possibly the recess (7) to the right of the atrium, in house I8. The north-east corner-room (3) of the Casa del Menandro has remains of a Third Style decoration on all except the north wall, which is a later replacement; ${ }^{16}$ it may well have been opened up as a shop at this stage. In the Casa del Fabbro the two large rooms on either side of the tablinum ( 8 and 9 ) received their definitive form complete with fine quality, late Third Style paintings.

The provision of the street-fountain at the north-east corner of the insula (pl. virib) is probably datable to this phase: it is normally assumed that running water was brought to Pompeii in the Augustan period with the construction of the aqueduct from Serino to Naples. ${ }^{17}$ This will have led to the offset in the north façade of house I. The recessed part of the façade behind the fountain was opened, whether immediately or within Phase $4 \mathrm{~B}$, to form a shop.

Most important is the addition of the upper storey of the peristyle in the Casa degli Amanti (pl. Ixa). It must be later than the peristyle of the Casa del Menandro (Phase 3 B), because there is a kink in the north wall representing the Menandro peristyle's south-west corner. The late Third Style paintings in the ground-floor peristyle of the Casa degli Amanti are probably either contemporary with or earlier than the construction of the second storey, because they are finished off flush with the stair-well, and are overlapped by the rough-cast plaster which coats the wall alongside the stair. A contemporary date is most likely, since it is difficult to believe that the upper storey could have been constructed without extensively damaging any pre-existing decoration in the lower storey. The floor of the upstairs triclinium employs a type of decoration dated by De Vos to the Imperial period at Pompeii: opus signinum decorated with a network of lines of tesserae and a piece of marble marking the centre of each element in the pattern. ${ }^{18}$ The reinforcing of the pillar between the atrium and the peristyle with quoins of brickwork and opus listatum is perhaps also to be connected with the upstairs development.

\section{Phase 4 B: ?Transitional Third-Fourth Style (c. A.D. 5o) (fig. 12)}

This phase is represented by the construction of the main part of the south-eastern quarter of the insula, including the finer rooms on the east side of the Menandro peristyle, the slaves' rooms behind, and the yard to the south. The whole of the block comprising corridor 16 , rooms $18-20$, the yard (34) and rooms $35-9$ were constructed ex novo after a brutal clearing operation involving the demolition of an earlier building or buildings on a slightly different alignment (of which the remains under the floor of oecus 18 are the only clear evidence). The structural technique is careful, a kind of opus incertum with largish facing rubble of various materials (Sarno limestone, tufo, red cruma, and grey lava, all carefully and evenly distributed) and quoins chiefly of opus listatum (pl. xa), but also 


\section{PHASE 4B}

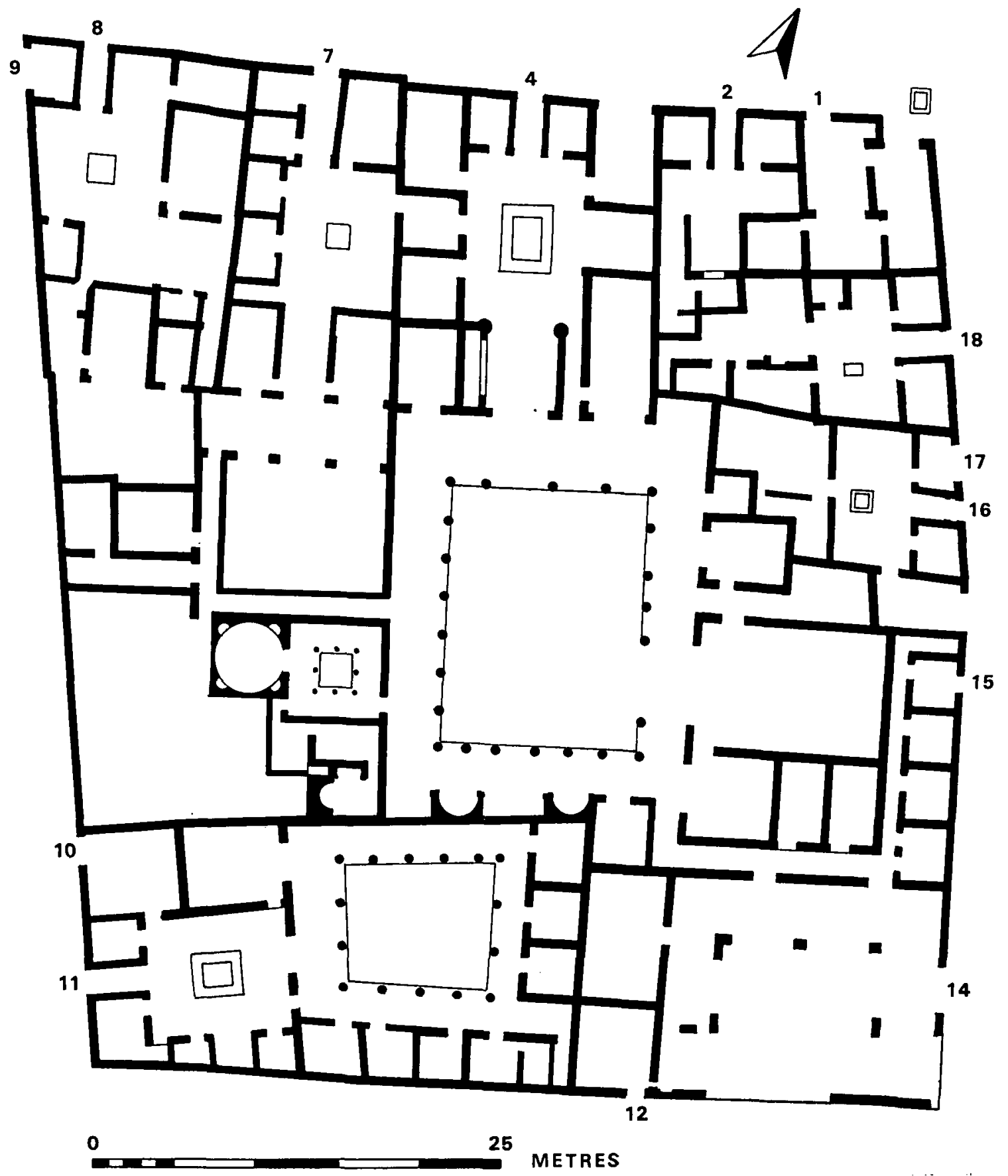

FIG. 12. Plan of Phase $4 \mathrm{~B}$

Drawn by Roger Ling 
(at the yard entrance 14 ) of brickwork (fig. $5 ; \mathrm{pl} . \mathrm{xx} b$ ) and (at the north-east corner of the block, i.e. the exterior of the latrine 39 ) of rectangular blockwork (fig. $5 ; \mathrm{pl}$. xIa). At times the incertum grades into 'quasi-reticulate' or even true reticulate: to the left of the yard entrance (pl. Ixb); under the relieving arch in the east wall of room 39 (pl. xI); on the east wall of the first arm of the corridor $L$ where it opens from the south-east corner of the peristyle; and at the east end of the southern arm of the corridor, on the exterior of room $20 \mathrm{~b}$. The rubble facing includes no fragments of bricks and tiles except in the north wall of the actual stable (room 29); this presents a different appearance from the remaining walls of the yard (34) and may perhaps owe its more makeshift appearance to its function as a replacement for the earlier rear wall of room 2I, from which it may have reused some material.

The west and south walls of the pre-existing room 15 were also built or rebuilt at this stage, being provided with opus listatum quoins identical to those of the new rooms. But the relationship of rooms 17 and 40 to the new development is less clear. Room 40 was probably not initially accessible from the south: the stub of a return wall visible between it and room 39 (pl. $\mathrm{xI} b$ ) corresponds to a butt-joint in the façade and presumably joined the north-east corner of oecus $\mathrm{I} 8$, closing off the new service-quarter from the properties to the north. To judge from the blocked opening on the street (pl. xIb, at the left), room 40 was at this stage some form of shop, whether independent or already linked with house $\mathrm{I} 6$. The space occupied by room 17 may possibly have belonged to it, since the oblique line of the intervening wall is oddly at variance with the strict rectangularity of the rooms to the south, and there is a butt-joint close to its junction with the wall of oecus I8. On the other hand, there seems no point in the existence of passage $x 6$ between rooms 15 and 18 if it was not serving the space behind; so we can only conclude either that room 17 was created, despite its irregular shape, as part of the Phase $4 \mathrm{~B}$ operation, or alternatively that it had already belonged in some form to the Casa del Menandro in the preceding phases. ${ }^{19}$

The dating of this phase is difficult, since the present decorations appear to be secondary (see below, Phase 5). A possible clue is provided by a piece of late Third Style painting (phase IIb, according to De Vos) ${ }^{20}$ now exhibited in exedra 13 together with fragments of stucco-work found by Maiuri in the filling of the demolished structures beneath the floor of oecus I8. If the painting comes from the same source as the stuccoes, it affords a terminus post quem for Phase $4 \mathrm{~B}$. Alternatively, given that the scale of the column shown in the painting would imply derivation from a very large room, the piece may even have formed part of the original decoration of oecus $\mathrm{I} 8$ : it could still have been sealed beneath the present pavement, since this is higher than the level of the door-sills and may well have been laid when the room was redecorated. This would give a date of $c$. A.D. 40-50. A much later date is excluded by the fact that the secondary decoration of oecus 18 must also be fitted before the earthquake of A.D. 62 .

Another clue is the narrowing of the entrance of oecus II. The walls with which the narrowing was achieved contain fragments of First Style stucco-work which could have been derived from the demolition-work on the east side of the peristyle (cf. the remains visible beneath room 18 ), while the narrowing of the doorway of oecus I I might logically accompany the creation of the much larger oecus 18 . The delicate green wall-decoration which was now applied in room in belongs to the transitional phase between Third and Fourth Styles, and points to a date about A.D. $5^{\circ}$. 
The structures to west and south of the stable-yard are less homogeneous in style and less regular in plan, so are probably to be attributed to earlier or later phases. Rooms 29 and $3 \mathrm{Ib}$ form a unit which is structurally later, since it meets the north wall of the yard area in a straight joint; but it is doubtful whether the interval which separates it from the main building phase is very large, and it could well be part of the same programme.

Another event which can perhaps be linked with the modifications of Phase $4 \mathrm{~B}$ is the rebuilding of the west street-wall of house 8 and the conversion of its front corner-room into an independent shop (no. 9). The structural style, with its facing of largish incertum, incorporating all the main types of building stone, and with opus listatum quoins (pl. xIIa), is very similar to that in the south-eastern quarter.

Phase 5: Fourth Style (c. A.D. 50-79) (not illustrated: cf. fig. 2)

The majority of the decorations of the Casa del Menandro belong to the early Fourth Style (before A.D. 62), and it was undoubtedly in this period that the main part of the house achieved its final form. The major change was the creation of the shop-complex 5-6 straddling the corners of the house and its neighbour, the Casa del Fabbro, with an upstairs apartment above the west range of the Menandro atrium. This presumably led to the addition of the front wall to the former right ala (room 7), while the doors to the right of the atrium and the ceilings of the rooms behind them $(5-7)$ were all lowered to accommodate the new flat. The decoration of room 7 is in the manner of the Third Style, but this is probably an imitative Third Style contemporary with the early Fourth Style paintings of the atrium, tablinum and left ala. ${ }^{21}$

As a result of the creation of the shop and flat astride the angles of houses 4 and 7 , the door linking the Menandro's room 6 with the atrium of house 7 was blocked. Probably the two houses were now separated again; corridor $\mathrm{M}_{2}$ was closed at its north end; the splay windows opening into it from the garden were blocked ( $\mathrm{pl}$. virb); and the garden now became the exclusive property of house 7 .

The peristyle area of the Casa del Menandro was also altered before the earthquake of A.D. 62. The doorways of rooms 18 and 19 were both narrowed, and the peristyle itself, room 12 and rooms $15-18$ were now redecorated in the early Fourth Style. Fragments of plaster from the peristyle and from the ceiling of room 18 were identified by Maiuri in a deposit of debris in the cellars beneath the bath-block, and the obvious inference is that the paintings had been damaged by, and were therefore prior to, the earthquake of $62 . .^{22}$ De Vos also draws attention to a graffito in the plaster of room 19 apparently naming the consul of A.D. $55^{23}$

Chief among the other alterations ascribable to this last phase must have been the building up of the area round the stable-yard in the south-eastern sector, including the creation of the thermopolium (I 10, I3: pl. Ixb), at first assessible from a back door in the west wall but later blocked off; the building of rooms 32 and 33, perhaps accomplished shortly before A.D. 79 , since they were being plastered at the time of the eruption; the reorganization of room $3 \mathrm{r}$, now closed off from $3 \mathrm{Ib}$ (which thus became an independent one-room unit); and the development and enlargement of the upstairs accommodation. The latter is difficult to understand in detail, since so much of the upper storey has collapsed, but the narrowing and lowering of the opening on the west side of the yard ( $\mathrm{pl} . \mathrm{x} b)$ ), together with the insertion of ceiling beams in the portico behind it and of a lintel across the west end of the 
north portico, testify to the presence of upstairs rooms, probably accessible from a wooden stair against the south wall of the stable (29). Another stairway was constructed in the southeast angle of the corridor, as a result of which the door which had opened from here into the yard (34) was now blocked and turned into a window (pl. $\mathrm{x} a$ ). To avoid the obstruction in the corner of the corridor, the front part of room $20 \mathrm{w}$ was hived off by a partition wall and became a passage opening through a new door into the corridor's eastern arm. This stairway served an upper storey above rooms 20 and $20 a-b$, rooms $35-8$ and probably the north and east sides of the stable-yard. The foot of the stairway was braced by fragments of the columns taken from the atriolum of the bath-suite and would therefore seem to post-date the earthquake of A.D. 62 (see below).

Another development which is later than Phase $4 \mathrm{~B}$ is presumably the incorporation of house $\mathrm{x} 6$ into the Menandro complex, achieved by the closing of the shop in room 40, the demolition of the wall dividing it from the corridor to the south (pl. xib), and the opening of a door (if it did not already exist) into atrium $4 \mathrm{I}$. The space formed by the merging of rooms 39 and 40 now apparently became an open yard.

It is remarkable that so little activity in the insula can be directly connected with the effects of the earthquake of A.D. 62. The only certain signs of it are repairs in the façade of the Casa degli Amanti, including the stitching of a lesion, the reconstruction of the upper part of the doorway, and perhaps also the upper cornering at the south-west angle, all carried out in a combination of rectangular blockwork and thick bands of brickwork (pl. xilb). The line of collapse at the doorway is reflected by the breakage of the Second Style wall-paintings in the fauces. These still awaited renewal in A.D. 79, though the atrium had been completely redecorated in the Fourth Style.

It is possible that the complete restructuring of the Menandro bath-suite, which was in progress in 79 , may have been promoted indirectly by earthquake damage: it would not be surprising if the south and west walls of the laconicum (room 49), which appear from the position of the underlying cellar walls to have been less thick than the north and east ones and therefore less able to withstand the thrust of the dome, collapsed in $\mathbf{6 2}$. There are, in fact, signs of an earthquake lesion in the wall of corridor $M$ at the point of junction between the atriolum (46) and laconicum. The alterations, including the demolition of whatever room or rooms existed in the south-west part of the bath-suite, the construction of the praefurnium behind the apse of the caldarium (48), and the razing of the wall between the atriolum and the tepidarium (47), would then have followed. The caldarium had been largely redecorated by the time of the eruption, but the Second Style paintings of the atriolum and tepidarium were still in process of being removed. ${ }^{24}$

Elsewhere in the insula various modifications can be dated to the period of the Fourth Style: for example, the closing of the shop in room 2 of house I (Fourth Style paintings in room 4), the creation of room 6 and the upper storey behind the atrium of house 8 , the creation of the taberna I I0, 2 and the addition of the upper storey in I Io, 3.

\section{General Historical Points}

The analysis of phases in insula $I$ ro illustrates a number of well-known factors regarding the social history of Pompeii.

Firstly, the addition of upper storeys appears to be a relatively late development. ${ }^{25}$ 
Apart from the upstairs rooms at the front of the Casa degli Amanti, which probably belong to the original construction, no example appears to be earlier than about the mid first century A.D. The upper storey round the peristyle in the Casa degli Amanti is associated with a redecoration of the ground floor in the late Third Style; the creation of the flat above the right side-range of the atrium in the Casa del Menandro probably coincided with the redecoration of the atrium and room 7 in the early Fourth Style; the room above Menandro rooms 20 and 20a-b is decorated in the Fourth Style; the upstairs rooms at the front of I Io, 2-3 yielded fragments of Fourth Style painting; and the installation of upper storeys in houses 7 and 8 seems to have been accompanied by ground-floor redecorations in the Fourth Style. It is clear that in our insula, as in many others, pressures on living space were by the mid first century A.D. forcing property owners or their tenants to build upwards where previously they had been able to find sufficient accommodation at ground-floor level.

Secondly, there was an increasing tendency during the last century of the insula's existence to open up shops and cafés along the street-fronts, often at the expense of the front rooms of houses. The date of $\mathrm{I} I \mathrm{IO}, \mathrm{I} 7$, with its brick jambs (fig. 5 ; pl. vib), is uncertain but can hardly antedate the early Augustan period. The shop in room 2 of house I ro, I post-dates the installation of the street-fountain outside, which in turn must post-date the building of the Augustan aqueduct. A possible shop in room 3 of the Casa del Menandro was perhaps opened during the period of the Third Style. The thermopolium I 10, 2 was probably opened during the time of the Fourth Style, in which it was decorated; and the thermopolium I Io, I3 post-dates the building of the Casa del Menandro's stable-yard area in Phase 4 B (cf. pl. $\mathrm{xx} b$ ). The shop I 10, 5 which straddles the front corners of the Casa del Menandro and the Casa del Fabbro was created, along with the upstairs flat I ro, 6, at the time of the early Fourth Style. All this bears witness to the increasing strength of the small commercial classes in the city, and perhaps to increasing traffic on the streets round our insula. One imagines that the new shops remained the property of the proprietor from whose house they had been carved: it is significant that in the final phase the façades of the Casa del Menandro and I IO, 5/6 received identical decorations. The shops may in some cases, especially where they remained accessible from the house, have been operated by the owner himself, perhaps through the agency of a trusted freedman. The thermopolium no. 13 had a door at the rear which was later blocked; if this gave into the service-quarters of the Casa del Menandro, rather than simply into a storage space, it might indicate the transition from a freedman to an independent shopkeeper. Presumably most of the shops were rented out to such independent tenants. For the leasing of shops and apartments in large Pompeian houses there is invaluable evidence from other parts of the city in the form of the painted notices referring to leases in the Insula Arriana Polliana and in the property of Julia Felix (the latter specifying a five-year term). ${ }^{26}$ Such notices are datable shortly before the eruption, because they would have been deleted as soon as their validity had expired; and they provide a good index of the way in which the old mansions, like the big Victorian houses in many present-day English cities, were beginning to be broken up into rented accommodation, often no doubt by absentee owners.

It should, however, be observed that the trend towards the creation of shops was not entirely one-way. At least one shop (that in room 2 of house $\mathrm{I}$ ) was closed up before the eruption; and so too were the possible shops in rooms 3 and 40 of the Casa del Menandro. 
The situation was obviously fairly fluid, despite the underlying trend. This should not surprise us: all sorts of factors, such as deaths, bankruptcies and changes of ownership, not to mention the social upheaval caused by the earthquake of 62 , must have affected the course of events.

The chief owners in our insula were of course the proprietors of the Casa del Menandro. It is interesting to observe the way in which they were able to take over or destroy parts of neighbouring houses, for example the Casa del Fabbro (before Phase 5) and the early house under oecus $\mathrm{I} 8$. One wonders whether the Menandro's owners, perhaps in the last years a branch of the gens Poppaea, ${ }^{27}$ did not in fact own the whole insula or a large part of it; they could then, if they so wished, take over other houses when leases expired. At the very least they had the financial resources to buy up other houses when they came on the market.

To judge from the amount of accommodation available in the south-eastern quarter after the Phase 4 B rebuilding, the Casa del Menandro in its last period had a large servicestaff: the identical rooms $35^{-8}$ along the east side of the insula were certainly slaves' bedrooms, and a similar series ran above. This was a large establishment, and the owner was a man of substance. At the same time he wished to maintain a life-style appropriate to his means and to distance himself somewhat from the workaday side of the establishment. The independent entrances on the east side of the insula, and the manner in which both this quarter and the kitchen area to the west of the peristyle are hidden at the end of long, angled corridors, demonstrates a concern to keep apart the 'show' part of the house and the servicequarters, and perhaps even to avoid social mixing.

The wealth of the owners, as of other Pompeian families, rested partly on agriculture, and a large part of the staff may have been engaged in working an estate outside the city. Among the finds from the rooms round the stable-yard, in addition to the farm-cart, were numerous amphorae and agricultural implements. Similar implements were found in the atrium of the attached house I I0, I6. Perhaps, as Maiuri and Della Corte suggest, ${ }^{28}$ the freedman Q. Poppaeus Eros, whose skeleton was found in room 43, was a bailiff or estate manager employed by the proprietor.

If the dominant family in the insula owed its wealth to land-holding and agriculture, the lesser families, whether or not they were tenants of the Menandro's owner, seem in the last years to have been small craftsmen. We can identify the workshop of a joiner in the Casa del Fabbro and that of a weaver in the corner-house I ro, 8.29 The occupation of the residents of the Casa degli Amanti is unknown, since few finds were recovered in the excavation, but the quality and elaboration of the Fourth Style decorations suggest a somewhat better-off family than those in the smaller houses. Of the other small premises, I 10, 2 and I 3 were obviously bars, and I Io, 6 was apparently a fullery. ${ }^{30}$ Finally it has been suggested, on the basis of graffiti, that the upstairs flat I IO, 5 served as a bordello. ${ }^{31}$

All this gives a hint of the information which can be gleaned on the social history of the insula, and which further work by the British team will refine and amplify.

Further seasons are planned for the next four years.*

\section{$S U M M A R Y$}

A British team has been working since 1978 upon a programme of documentation and analysis in the Insula of the Menander at Pompeii, one of the irregular city-blocks situated immediately 
to the west of the old part of the city in an area which was developed from the early fourth century B.C. onwards. Study of the structural techniques, of wall-abutments, and of anomalies in plan can be used in conjunction with the evidence of painted wall-plaster to identify five main phases in the building-history: Phase I (fourth-third centuries B.C.), Phase 2 (second and early first centuries B.C.), Phase 3 (c. 80-c. I5 B.C.), Phase 4 (c. I5 B.C.-c. A.D. 50), Phase 5 (c. A.D. 50-79). These illustrate a complex pattern of changing property-boundaries, but underline the general trend towards increasing commercialization and greater pressure upon living-space in this area of the city. There is also interesting evidence of the economic basis of life in the individual houses during the years immediately before 79.

\section{LIST OF ABBREVIATIONS}

Andreae and Kyrieleis B. Andreae and H. Kyrieleis (eds.), Neue Forschungen in Pompeji (Recklinghausen, 1975).

Beyen 1938 , 1960

H. G. Beyen, Die pompejanische Wanddekoration vom zweiten bis zum vierten Stil, I (The Hague, I938), II, I (1960).

Bragantini et al.

I. Bragantini, M. De Vos and F. Parise Badoni, Pitture e pavimenti di Pompei, Regioni I, II, III (Repertorio delle fotografie del Gabinetto Fotografico Nazionale) (Rome, I98I).

Della Corte 1965

M. Della Corte, Case ed abitanti di Pompei, $3^{\text {rd }}$ edn. (Naples, I965).

De Vos 1977

De Vos 1979

M. De Vos, 'Primo stile figurato e maturo quarto stile negli scarichi provenienti dalle macerie del terremoto del 62 d.C. a Pompei', Mededelingen van het Nederlands Instituut te Rome, xxxix (1977), 29-47.

M. De Vos, 'Mosaici e pavimenti', in F. Zevi (ed.), Pompei 79. Raccolta di studi per il decimonono centenario dell' eruzione vesuviana (Naples, 1979), pp. I6I-76.

Elia

La Rocca and De Vos O. Elia, 'Pompei-relazione sullo scavo dell' Insula $\mathrm{X}$ della Regio I', Notizie degli scavi (1934), 264-344.

E. La Rocca, M. and A. De Vos, Guida archeologica di Pompei (Milan, I976).

Maiuri 1933

A. Maiuri, La Casa del Menandro e il suo tesoro di argenteria (Rome, I933).

Pompei I748-I980 Pompei I748-I980: i tempi della documentazione (exhibitioncatalogue, Rome, r98r).

\section{NOTES}

1 Cronache pompeiane, v (1979), igr f.; Pompei I748-I980, pp. $94 \mathrm{f}$.

2 On insula I Io and the other irregular insulae between the Altstadt and the eastern quarter, see H. Eschebach, Die städtebauliche Entwicklung des antiken Pompeji (Heidelberg, 1970), pp. 52, 59; J. B. Ward-Perkins, in F. Zevi (ed.), Pompei 79. Raccolta di studi per il decimonono centenario dell' eruzione vesuviana
(Naples, 1979), pp. 35, 37. Eschebach dates the eastern quarter to the time of the Roman colony (op. cit., pp. 56 f., 60), but such a late date is excluded by the presence of First Style decorations.

3 Maiuri 1933; the architectural phases summarized on pp. 22-5. More thorough is the analysis by Beyen 1960, pp. 120-37 (though confused and in some details defective). 
${ }^{4}$ Elia.

5 Fournal of Roman Studies, xxiii (1933), 125-38; cf. La Rocca and De Vos, pp. 26-8, 3 I ff.; T. and J.-P. Adam, 'Le tecniche costruttive a Pompei: una documentazione a cura del C.N.R.S.', in Pompei I748-I980, pp. 96-104.

${ }^{6} \mathrm{I}$ use this term rather than opus mixtum to avoid confusion with opus mixtum of brick and reticulate.

7 See especially Beyen 1938, 1960; F. L. Bastet and M. De Vos, Proposta per una classificazione del terzo stile pompeiano (The Hague, I979).

8 I am grateful to Paul Arthur, Chris Going and David Williams for identifications, and to the latter for fabric analysis of the sigillata fragment.

${ }^{9}$ Birmingham Ph.D. dissertation, 1980 .

${ }^{10}$ It is too shallow ever to have served a cistern. On its decoration see De Vos 1979, p. I72.

11 It is dated to the First Style by Bragantini et al., p. III; cf. E. Pernice, Pavimente und figürliche Mosaiken (Die hellenistische Kunst in Pompeji, vi) (Berlin, 1938).

12 N. Fadda, in Andreae and Kyrieleis, pp. I6I, 165 .

13 See, e.g., H. Lauter, in Andreae and Kyrieleis, pp. $\mathrm{I}_{48} \mathrm{f}$.

14 Cf. the discussion by Beyen (1960, pp. $130-4$ and fig. 57).

15 See E. Fabbricotti in Cronache pompeiane, ii (1976), Io6 f.; cf. 63 f., 65 f., 77 f., figs. 26,28 , 33. On the Stabian Baths, H. Eschebach, ... "laconicum et destrictarium faciund... locarunt. . .."Untersuchungen in den Stabianer Thermen zu Pompeji', Mitteilungen des Deutschen Archäologischen Instituts. Römische Abteilung, $1 \times x x$ (1973), 235-42. On the Suburban Baths, A. Maiuri, Ercolano, i nuovi scavi (Rome, I958), pp. I68 f., figs. II 4,122 (a later and smaller example). At the centre of the Menandro laconicum is a cylindrical cavity which perhaps served as a receptacle for a brazier; the absence of a plunge-bath precludes the possible alternative identification as a frigidarium, like those in the Forum Baths at Pompeii, the City Baths at Herculaneum or (after conversion) the Stabian Baths at Pompeii (cf. R. Ginouvès, Balaneutike (Paris, I962), pp. 202 f., n. 5).
16 The decoration is indicated as Third Style on the colour-coded plan of wall-paintings in Pompei I748-I980, but Beyen describes it as early Fourth Style (1960, p. 124, n. 5). Close examination is now impossible, because the room is inaccessible

17 E.g. La Rocca and De Vos, p. 25. Cf. H. Eschebach in Cronache pompeiane, v (1979), 29-32; but, with arguments for a piped watersupply as early as the second century B.C., ibid., 56.

18 De Vos 1979, p. 172.

${ }^{19}$ As Beyen supposed: 1960, p. 134.

20 Bragantini et al., p. I 2 I.

21 I defer here to the judgement of Dr. W. Erhardt, who has kindly discussed the Third Style decorations of the insula with me. Cf. Bragantini et al., pp. I $66 \mathrm{f}$.

22 Maiuri 1933, pp. 227 f., n. 20; De Vos 1977, pp. 38,45 , n. 59.

${ }_{23}$ M. Della Corte in Notizie degli Scavi (1933), p. 290, n. 136; De Vos 1977, p. 39 (quoting the wrong year).

24 Maiuri 1933, pp. 121-4.

25 Later than Beyen, e.g., thought: I960, pp. $124-6$.

26 Corpus Inscriptionum Latinarum, IV (1871), nos. 138 (cf. Addenda, p. 193), I 136; cf. A. Mau, Pompeji in Leben und Kunst, and edn. (Leipzig, I908), pp. 507 f.; La Rocca and De Vos, pp. $244,325 \mathrm{f}$.

27 Maiuri 1933, pp. 17-22; Della Corte 1965, pp. 293-5.

28 Maiuri 1933, pp. 20, 20 I f. ; cf. Della Corte 1965, pp. 294, 297.

29 Elia, pp. 292 (n. 1), 3 I 7 ; Della Corte 1965, pp. 300,301 ; La Rocca and De Vos, p. 172.

30 Elia, p. 276; Della Corte 1965, p. 299.

31 Della Corte 1965 , p. 299; La Rocca and De Vos, pp. $174 \mathrm{f}$.

* In addition to those thanked in the text and notes I am grateful to the following, who have visited the site and discussed its problems: Drs. Alix Barbet, Irene Bragantini and Mariette De Vos, Herr R. Meyergraft, Dr. F. Seiler, and Professor V. M. Strocka. I have also benefited from continuous discussions with Sheila Gibson, Lesley Ling and Diana Mitchell, and from the preliminary work done by Henry Hurst in 1978 . 